\title{
Velkomoravské pohřebiště v Rajhradicích
}

Great Moravian burial ground in Rajhradice

\author{
Soňa Hendrychová
}

\begin{abstract}
Abstrakt
Předložená práce předkládá celkové zhodnocení výzkumu velkomoravského pohřebiště v Rajhradicích (okr. Brno-venkov), odkrytého v letech 1952-1953 a 1975. Práce vychází z katalogu pohřebiště publikovaného spolu se sousedním pohřebištěm v Rajhradě Čeňkem Staňou. Práce sleduje jednotlivé aspekty pohřebního ritu na nekropoli, hodnotí hrobový inventář, na jehož základě nabízí datování lokality a jeho zařazení do kontextu velkomoravských pohřebišt'.
\end{abstract}

\begin{abstract}
The presented work focuses on the overall evaluation of the Great Moravian burial ground in Rajhradice (Brno-Country District) uncovered in 1952-1953 and 1975. The work is based on a catalogue of the burial ground published along with the neighbouring burial ground in Rajhrad by Čeněk Staňa. It follows the individual aspects of the burial rite at the necropolis, evaluates the grave inventory, dates the burial ground based on it and puts it into the context of Great Moravian burial grounds.
\end{abstract}

Klíčová slova: Rajhradice - Velká Morava - pohřebiště - chronologie Key words: Rajhradice - Great Moravia - graveyard - chronology

DOI: $10.14712 / 25707213.2018 .1$

\section{Úvod}

Předložený článek vychází z bakalářské práce obhájené v roce 2011 (Hendrychová 2011) a přináší zhodnocení velkomoravského pohřebiště v Rajhradicích. Bakalářská práce byla vytvořena na základě posmrtně publikovaného katalogu Čeňka Stani, který obsahuje rovněž katalog sousedního pohřebiště na katastrálním území Rajhradu. Během analytického zhodnocení lokality byly využívány databázové programy a GIS, byly sledovány jednotlivé aspekty pohřebního ritu a jejich vazby na pohlaví a věkové kategorie, přičemž většina těchto vztahů je vyjádřena také graficky. Zpracování archeologického materiálu nemělo v žádném případě suplovat již publikovaný katalog. Vyhodnoceny byly jednotlivé kategorie předmětů $\mathrm{z}$ hrobových inventářů za účelem chronologického a sociálního zařazení pohřebiště, v hrobech byly sledovány kombinace jednotlivých typů předmětů. Výsledkem je vyhodnocení celého pohřebiště po stránce prostorové, chronologické a sociální.

\section{Dějiny bádání a prŕírodní podmínky}

Záchranný archeologický výzkum na rajhradickém pohřebišti byl zahájen na podzim roku 1952 poté, co Československé státní statky rozšiřovaly v místech kolem kóty 213,280 m n. m. na k. ú. Rajhradice vinohrad (Plán 1). Při hluboké orbě byly zachyceny hrobové jámy. Záchranný výzkum provedl v první fázi pracovník Archeologického ústavu ČSAV v Brně J. Král. V sondách, které měly zjistit rozsah pohřebiště, bylo prozkoumáno celkem 84 hrobů, z nichž 67 bylo raně středověkých. Práce trvaly za velmi nepř́íznivých klimatických podmínek až do prosince (Staňa 2006, 11). Výzkum byl záhy publikován pod názvem Rebešovice, nebot' autoři (J. Ondráček, J. Nekvasil) přihlédli k tradičnímu označení lokality (Staňa 2006, 17).

Práce pokračovaly v období od března do června roku 1953 pod vedením J. Nekvasila a během výzkumu bylo odkryto dalších 140 raně středověkých hrobů. Ve dnech 8. až 9. 7. 1953 byl výzkum dokončen pod vedením Č́. Stani. Odkryto bylo dalších šest raně středověkých hrobů. Antropologický materiál 


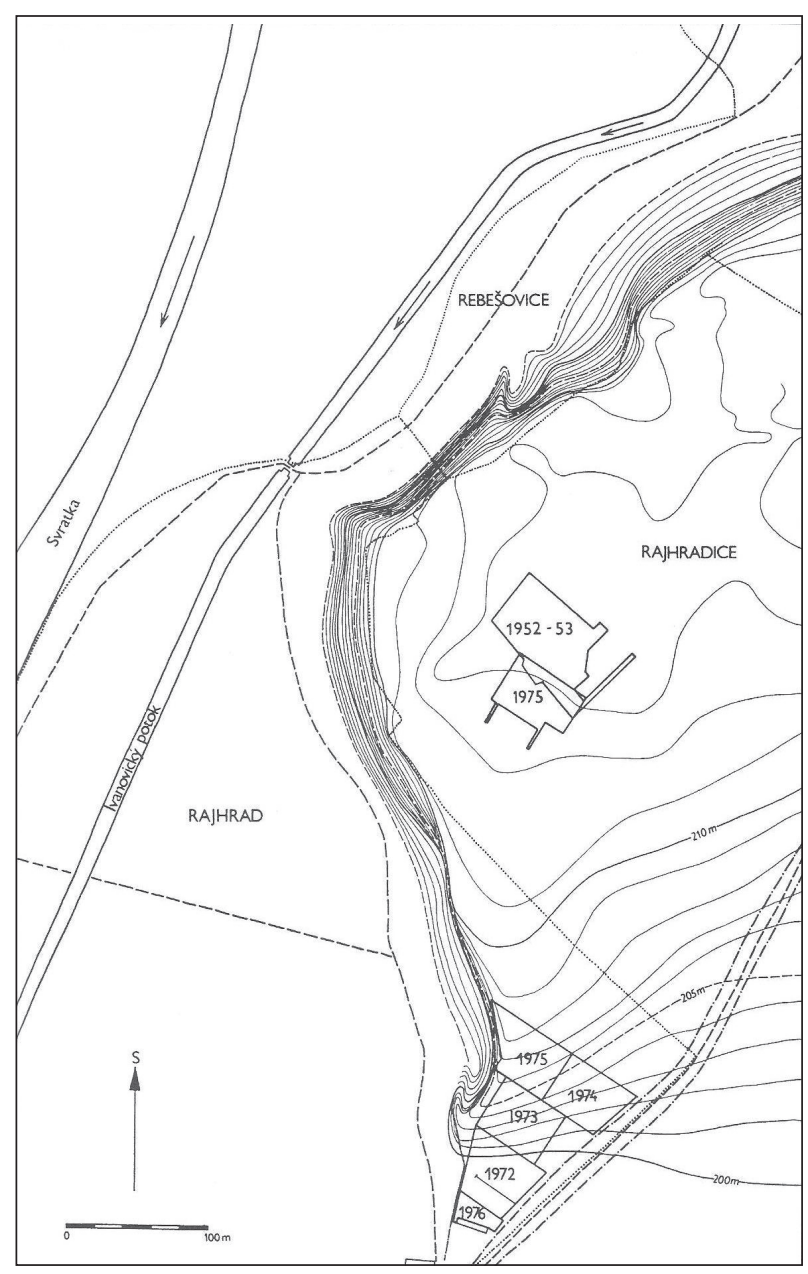

Plán 1. Odkryté plochy na pohřebištích v Rajhradě a Rajhradicích (podle Staña 2006). - Plan 1. Uncovered areas at Rajhrad and Rajhradice burial grounds (after Staňa 2006).

z hrobů, prozkoumaných v letech 1952 až 1953, zpracoval Jan Jelínek z MZM (Staña 2006, 12).

Po objevu pohřebiště v Rajhradě $\mathrm{v}$ roce 1972 se Č. Staňa vrátil v roce 1975 na jižní okraj plochy, která byla zkoumána v letech 1952 až 1953. Mimo jiné prozkoumal 27 raně středověkých hrobů. Antropologický materiál z této fáze výzkumu zpracoval Milan Stloukal. Během této etapy byl stanoven jižní a jihozápadní okraj pohřebiště. Během všech sezón bylo celkem zjištěno 239 raně středověkých, 85 únětických a 11 hrobů z doby stěhování národů. Jeden hrob byl datován do období přechodu mohylové a velatické kultury (Staňa 2006,12). Plocha pohřebiště byla pravděpodobně odkryta v úplnosti (plán 2), ojedinělý hrob mohl snad uniknout jen $\mathrm{v}$ jejím východním rohu (Staňa 2006, 22).

Návrší, na kterém se pohřebiště nachází, je jihozápadním okrajem hřbetu vybíhajícím z Tuřanské plošiny. Lemuje údolní nivu řeky Svratky jako strmá, přibližně $20 \mathrm{~m}$ vysoká terasa, jejíž přirozený vzhled

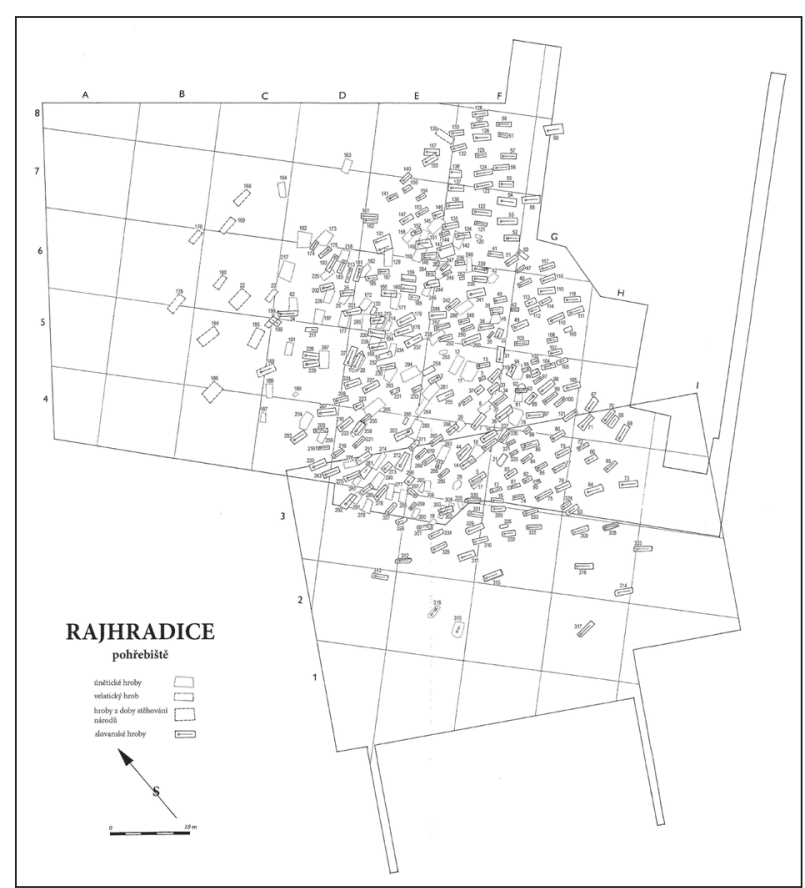

Plán 2. Rozsah zkoumané plochy s vyznačenými hroby (podle Staña 2006). - Plan 2. Extent of the examined area with the graves marked out (after Staña 2006).

byl v polovině 20. století narušen agrotechnickým zásahem, který v několika horizontech obnažil podložní hlíny a štěrky. Hřbet se ve svém závěru zvolna svažuje k jihovýchodu. Rajhradické pohřebiště se nachází na plošině návrší kolem kóty $213,280 \mathrm{~m} \mathrm{n}$. m. (Staňa 2006, 10).

Lokalita se nachází na fluviální štěrkopískové terase neznámého stárí, která se zvedá nad nivními uloženinami řeky Svratky. V těsné blízkosti pohřebiště tvoří podloží převážně jíly, slíny a písky třetihorního stáŕí (Kodym - Fusán - Matějka 1967). Nastíněné geologické poměry na lokalitě dobře odpovídají pozorováním Č. Stani. Plošinu návrší při kótě pokrývala až $80 \mathrm{~cm}$ mocná ornice, pod níž se objevil hrubý říční štěrk. V horní části svahu, asi 8 výškových metrů pod kótou, se objevilo značně nesourodé podloží, sestávající hlavně z jílovitých vrstev. Přibližně o 5 metrů níže se pod ornicí objevil jemný žlutý písek, který dále přecházel v žlutou jílovitou hlínu (Staňa 2006, 10). Podloží značně ovlivnilo zachovalost kosterního materiálu. Kostry v hrobech, které byly zapuštěny do štěrku na plošině návrší, byly ve špatném stavu, zatímco kostry uložené v písku a ve vápnitém jílu se zachovaly ve velmi dobrém stavu (Staňa 2006, 10). Podloží ovlivnilo také složení a mocnost ornice, výrazně ovlivněnou splachy (Staňa 2006,10). Z pedologického hlediska se pohřebiště nachází v oblasti černozemí s půdou převážně hlinitou s výrazným zastoupením prachu (Tomášek 2007). Klimaticky 
lokalita spadá do jedné z nejteplejších oblastí České republiky (dle Quittovy klasifikace oblast W2 (Tolasz a kol. 2007).

Z hlediska rekonstrukce původního vegetačního pokryvu se pohřebiště nachází na rozhraní oblasti lužního lesa s porostem jilmové doubravy, která se rozkládá v údolí řeky Svratky, a oblasti subkontinentálních teplomilných doubrav, konkrétně sprašové doubravy. V nejbližším okolí se dále nacházely přirozené porosty dubohabřin a lipových doubrav, a to konkrétně prvosenková dubohabřina (Neuhäuslová a kol. 2001).

\section{Demografie}

$\mathrm{Na}$ pohřebišti byly odkryty pozůstatky celkem 244 jedinců z 239 hrobů. Antropologický materiál z pohřebiště zpracovali RNDr. Jan Jelínek z MZM a RNDr. Milan Stloukal z NM, ovšem jejich poznatky nebyly publikovány. Při práci s antropologickými daty proto vycházím pouze z tabulek v katalogu obou pohřebišt' (Staňa 2006), které obsahují základní informace o věku a pohlaví zemřelých. Věk dospělých zemřelých je $\mathrm{v}$ katalogu uváděn s přesností na desetiletí, takže pro stanovení věkové kategorie používám členění na infans I (0-7 let), infans II (7-13 let), juvenis (14-20 let), adultus I (20-30 let), adultus II (30-40 let), maturus I (40-50 let), maturus II (50-60 let) a senilis (nad 60 let); (Stloukal a kol. 1999, 236), ačkoliv v současnosti je zřejmé, že takto přesné kategorie jsou neudržitelné (např. Brüžek 2008, 330-331).

Z 244 jedinců, kteří byli podrobeni antropologickému zkoumání, zůstalo 25 dospělých (tj. $10 \%$ všech zemřelých; procenta jsou zaokrouhlena na celá čísla) bez určeného pohlaví, u 24 zemřelých nebylo možné blíže odhadnout věk dožití. Dětí bylo na nekropoli 90 (tj. 37 \% všech zemřelých), příslušníků věkové kategorie juvenis bez určení pohlaví 30 (12\%), mužů 43 (18 \% všech zemřelých) a žen 56 (23\%). Strukturu pohřebiště dle pohlaví znázorňuje graf 1 .

Z 90 dětí zemřelo 53 (tj. $59 \%$ všech dětí) ve věkové kategorii infans I (0-7 let), dalších 29 (32 \% všech dětí) zemřelo ve věku 7-14 let (infans II) a 8 dětí nebylo možné do věkové kategorie zařadit. Na věkové zastoupení nedospělých jedinců na pohřebišti ukazuje graf 2. Je patrné, že nejvíce dětí umíralo ve věku do 7 let, zatímco po sedmém roce života úmrtnost dětí klesá, což odpovídá pozorováním M. Stloukala (Stloukal a kol. 1999, 370). Poměr mezi skupinou infans II a juvenis je však přibližně vyrovnaný, což neodpovídá předpokládanému poklesu úmrtnosti jedinců v rámci těchto kategorií.

Věk nebylo možno stanovit u tří žen (5\% žen) a u dvou mužů (4 \% mužů). Věkovou strukturu

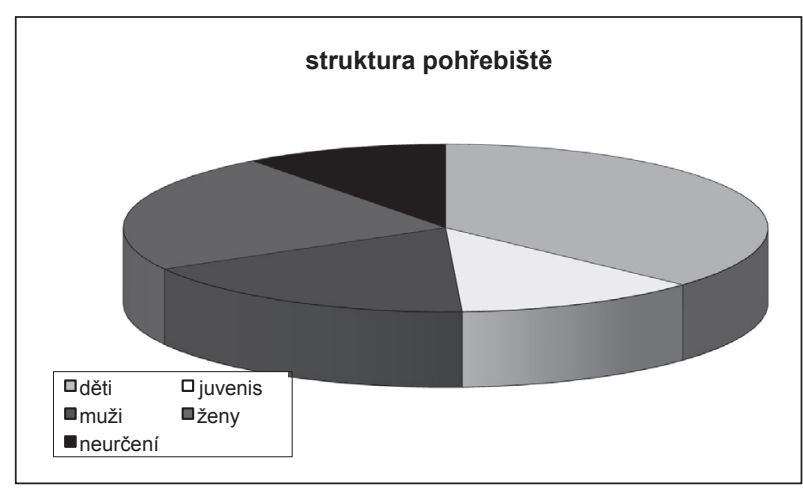

Graf 1. Struktura pohřebiště dle pohlaví. - Graph 1. Burial ground structure according to gender.

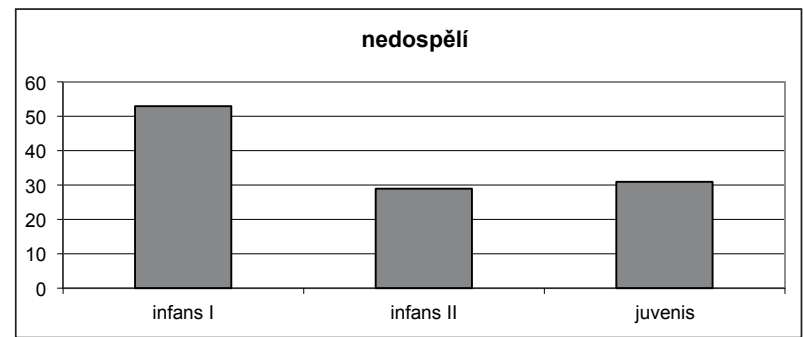

Graf 2. Věková struktura nedospělých jedinců. - Graph 2. Age structure of juvenile individuals.

mužů i žen ukazuje graf 3. Muži i ženy z Rajhradic umírali ve věkových kategoriích juvenis (1 žena) až maturus II. Antropologové nenalezli nikoho, kdo by se dožil kategorie senilis. Graf ukazuje, že úmrtnost ve věkových kategoriích je mezi pohlavími překvapivě poměrně vyrovnaná. V Rajhradicích nemůžeme sledovat jinde prokázanou (Stloukal a kol. 1999, 370) vyšší úmrtnost žen oproti mužům ve věku 20-30 let, ani mírný pokles úmrtnosti žen po 40 . roce. $\mathrm{Na}$ rajhradické nekropoli naopak ve věku nad 40 let zaznamenáváme nárůst úmrtnosti mužů i žen. Ve věku 50 až 60 let pak zemřela naprostá menšina zde pochovaných obyvatel (graf 4).

Početní poměr mezi muži a ženami vyjadřuje index maskulinity (Stloukal a kol. 1999, 370), který činí 767,857. Tomuto číslu se patrně nejvíc blíží index maskulinity 709,7 z nekropole při 4. mikulčickém kostele či hodnota $809,5 \mathrm{z}$ pohřebiště u 11 . mikulčického kostela (přehled Štefan - Krutina 2009, 189). Sousední pohřebiště v Rajhradě vykazuje index maskulinity nižší, a to 513,3 (Hanáková - Staňa - Stloukal 1986, 43).

Pro výpočet velikosti zde pohřbívající komunity použijeme Nemeskériho vzorec. Velikost komunity se vypočítá $\mathrm{P}=\left(\mathrm{D} \times \mathrm{e}_{0} / \mathrm{t}\right)+\mathrm{k}$, kde $\mathrm{D}$ je počet zemřelých, $\mathrm{e}_{0}$ naděje na dožití při narození, t doba trvání pohřebiště a k je korekční faktor, který tvoří desetinu t. Při předpokládaném trvání rajhradického 


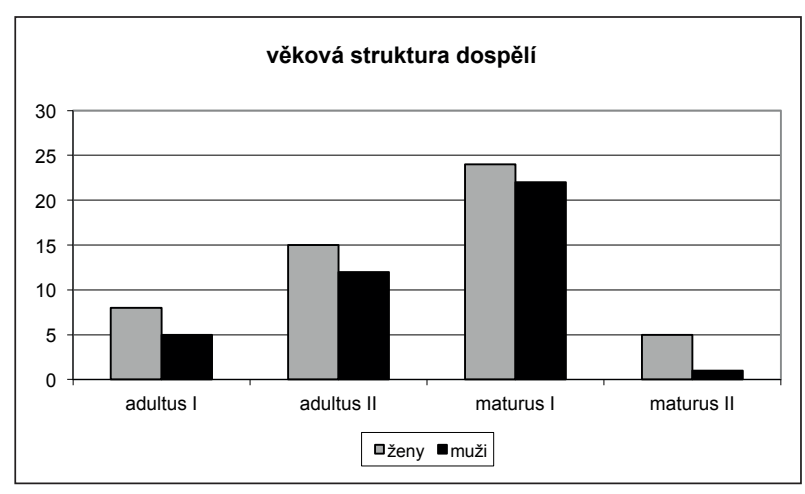

Graf3. Věková struktura mužů a žen. - Graph 3. Age structure of men and women.

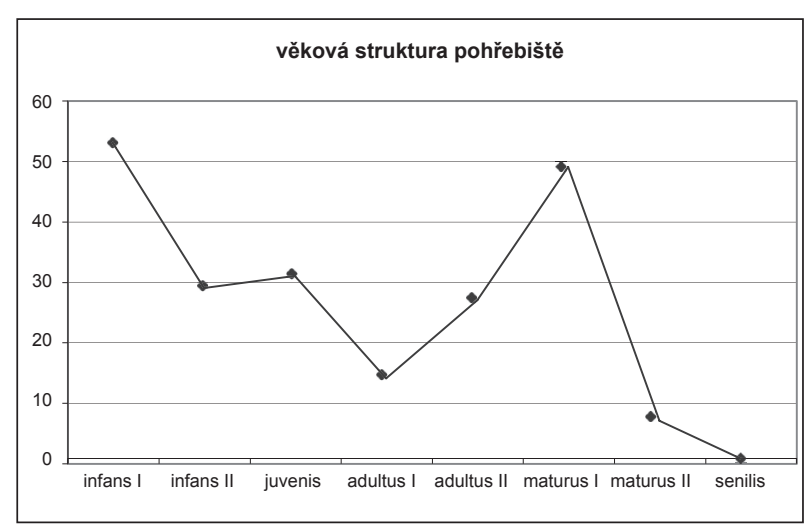

Graf4. Věková struktura pohřebiště. - Graph 4. Age structure of the burial ground.

pohřebiště 100 let ( $\mathrm{k}$ chronologickým závěrům blíže kapitola „Datování pohřebiště“; nekropole pravděpodobně sloužila ve 2 . polovině 9 . století s určitým přesahem do 10. století) a hodnotě $\mathrm{e}_{0} 27$ let (pro raný středověk s tímto číslem počítá např. Štefan - Krutina 2009, 184), dospějeme k počtu 76 osob, při možném trvání pohřebišse po dobu 50 let k hodnotě 137 osob (Stloukal 1999, 371). V obou př́padech by tedy šlo o početnou komunitu lidí.

\section{Pohřební ritus}

Při vyhodnocení jednotlivých aspektů pohřebního ritu se v zásadě opírám o data publikovaná $\mathrm{v}$ katalogu (Staňa 2006). Týká se to např́ḱlad určení věku a pohlaví, rozměrů hrobových jam i údajů o př́tomnosti či absenci konstrukcí v hrobových jamách. Pouze některé sporné a nejasné situace jsem ověřovala př́mo v nálezových zprávách. $\mathrm{V}$ následujícím textu budou sledovány nejrůznější charakteristiky pohřebního ritu od tvaru a rozměrů hrobových jam, přes různé typy úprav hrobových jam, po způsob uložení lidských ostatků v hrobě.
Z 239 hrobů měla naprostá většina (216 hrobů, tj. $90 \%$ ) obdélný půdorys se svislými stěnami a rovným dnem. Nepatrné množství hrobů mělo tvar lichoběžníku, oválu či nepravidelný půdorys. U dalších sedmi hrobů nebyl tvar zjištěn.

Délka hrobu byla víceméně přizpůsobena výšce jedince. Průměrná délka dětského hrobu byla $148,8 \mathrm{~cm}$, průměrná délka hrobu jedince kategorie juvenis $194,1 \mathrm{~cm}$, ženského hrobu $213,9 \mathrm{~cm}$ a mužského hrobu $234 \mathrm{~cm}$. Je tedy patrné, že až na několik výjimek je zachována závislost délky hrobové jámy na výšce postavy zemřelého. Šŕřka hrobových jam vykazuje také určitou závislost na pohlaví a věku jedince, až na několik výjimek platí, že užší jámy patřily dětem, zatímco dospělí jedinci měli hroby spíše širší. Průměrná šíŕka dětského hrobu byla $65 \mathrm{~cm}$, hrobu nedospělého jedince $68,3 \mathrm{~cm}$, ženského hrobu $73,4 \mathrm{~cm}$, mužského hrobu $79,6 \mathrm{~cm}$. Hloubka uváděná v katalogu Č. Staňou je počítána včetně skryté ornice, kterou Staňa považuje za $70 \mathrm{~cm}$ mocnou. V katalogu sice na tento fakt výslovně neupozorňuje, je to však patrné z nálezových zpráv (Král 1954; Nekvasil 1954; Staña 1954; Staña 1977). Z 239 hrobů na rajhradickém pohřebišti bylo méně než $100 \mathrm{~cm}$ zahloubeno jen 42 hrobů, z nichž převážnou část představují hroby nedospělých jedinců (jen 12 dospělých). Naprostá většina hrobů (celkem 133) byla hluboká 100 až $150 \mathrm{~cm}$, svou hloubkou se do dvou metrů vešlo 62 hrobů, z nichž většinu představovaly hroby dospělých jedinců a jen $16 \mathrm{z}$ nich patřilo nedospělým. Hloubky rovných dvou metrů dosáhly dva hroby. Průměrná hloubka dětského hrobu byla $115 \mathrm{~cm}$, věkové kategorie juvenis $125,3 \mathrm{~cm}$, ženských hrobů $135,5 \mathrm{~cm}$ a mužských $145,8 \mathrm{~cm}$. Opět tedy můžeme sledovat určitou vazbu na věk a pohlaví.

Kubatura jam byla pro snadnější určení vypočítána z průměrných zaokrouhlených hodnot rozměrů hrobových jam. Je nutné připomenout, že kubaturu hrobových jam zcela jistě ovlivnily splachy půdy, př́mo působící na hloubku hrobových jam (Staña 2006, 22).

Přehled kubatur hrobových jam v závislosti na věku a pohlaví přehledně znázorňuje graf $5 . \mathrm{V}$ zásadě platí pravidlo, že méně objemné hroby patřily nedospělým jedincům, byt' $\mathrm{v}$ hrobech menších než $1 \mathrm{~m}^{3}$ byly výjimečně pochovány i dospělé osoby. Největší hroby na lokalitě s kubaturou větší než $4 \mathrm{~m}^{3}$ patřily dospělým jedincům, a to jak mužům, tak ženám. Objem $4,12 \mathrm{~m}^{3}$ měl ženský hrob č. 179 , objem $4,21 \mathrm{~m}^{3}$ mužský hr. č. 52 . Hr. č. 53 a 54 o objemech 4,99 a $5,03 \mathrm{~m}^{3}$ náležely mužům, naprosto nejobjemnější hrob s kubaturou $5,5 \mathrm{~m}^{3}$ patřil ženě z hrobu č. 36 .

$\mathrm{Na}$ pohřebišti se nedá sledovat př́má závislost velikosti hrobové jámy na bohatství. Extrémně malé hroby dospělých jedinců (s objemem menším než $1,5 \mathrm{~m}^{3}$ ), patř́cí obvykle ženám a jedincům neurče- 


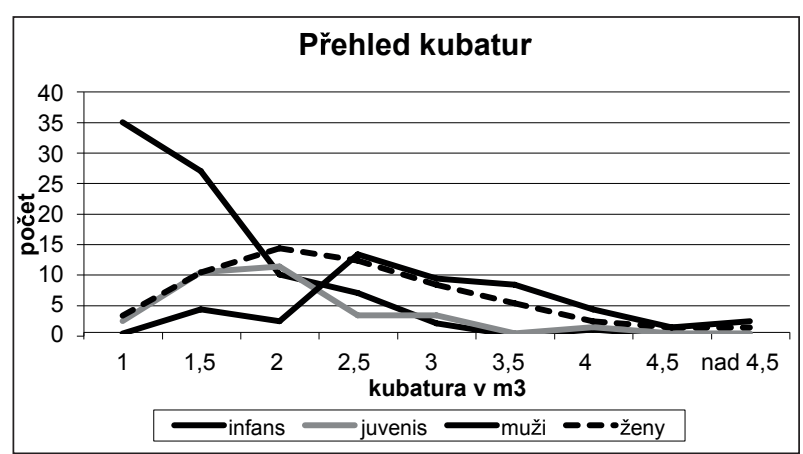

Graf 5. Přehled kubatury hrobů v závislosti na věku a pohlaví. - Graph 5. Overview of grave cubage depending on age and gender.

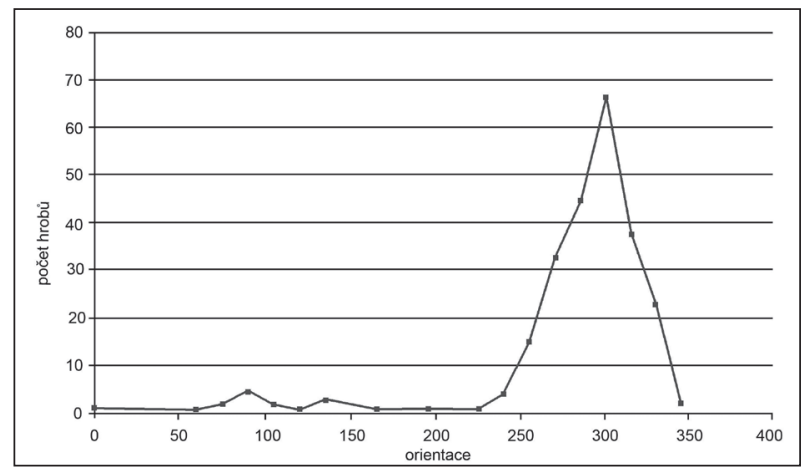

Graf 6. Přehled orientací hrobů (podle Staňa 2006). Graph 6. Overview of grave orientations (after Staňa 2006).

ného pohlaví, méně často mužům (4 hroby), byly sice $\mathrm{z}$ velké části bez výbavy (15 hrobů) či jen s velmi skromnou výbavou (8 hrobů), avšak zároveň není možné říct, že nadměrně objemné hroby jsou vybavené nadprůměrně. Celkem 14 největších hrobů (s objemem nad $3,5 \mathrm{~m}^{3}$ ) bylo z velké části vybaveno velmi skromně. Největší hrob na lokalitě (ženský hr. č. 36 , objem $5,5 \mathrm{~m}^{3}$ ) obsahoval nůž a vědérko. Naproti tomu se 8 hrobů na rajhradickém pohřebišti, které je možno považovat za výjimečně bohaté, nevyznačovalo extrémně velkými rozměry.

Orientace byla na pohřebišti popsána u 238 hrobů, u jednoho hrobu nebylo možno orientaci určit. Orientace jsou v katalogu (Staňa 2006) uváděny formou azimutů v tabulce. Na pohřebišti v Rajhradicích byli mrtví pochováváni hlavou k západu a tedy tváří k východu slunce. Přímo západovýchodní orientaci (azimut $270^{\circ}$ ) však na rajhradické nekropoli dodržovalo jen 6 hrobů, naprostá většina jich byla orientována s odchylkou k severu. Odchylky k jihu byly oproti severnímu směru méně četné. Orientace $\mathrm{S}-\mathrm{J}$ nebo J-S se na lokalitě nevyskytovaly. Za opačně orientované hroby pak můžeme považovat celkem 17 hrobů (7 \% všech hrobů). Tyto hroby obsahovaly zejména pozůstatky dětí (12 z těchto hrobů), ve dvou

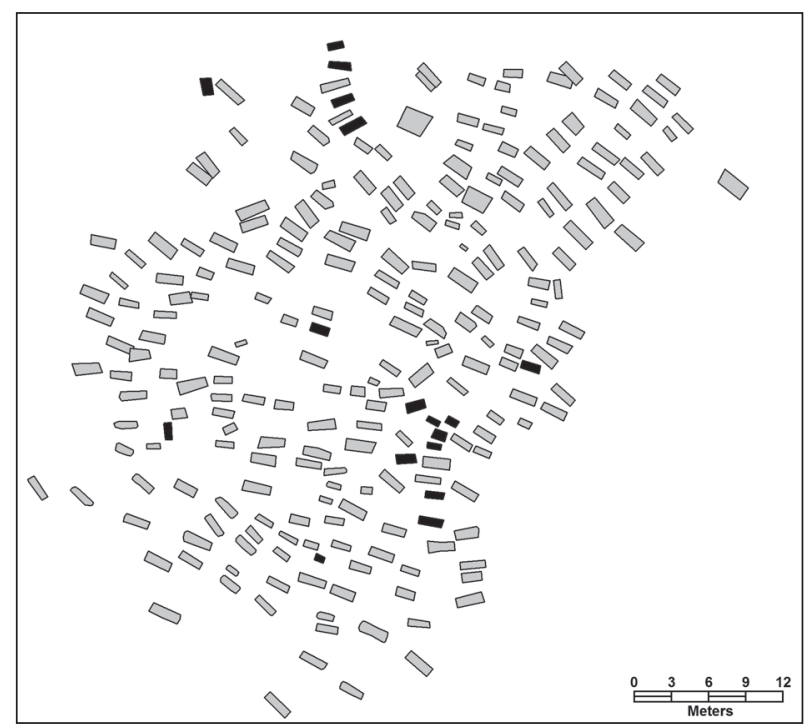

Plán 3. Opačně orientované hroby. - Plan 3. Graves with different orientation.

hrobech se nacházely ostatky neurčených dospělých jedinců, v jednom byla žena věkové kategorie adultus (č. 175), v dalším muž věkové skupiny maturus (č. 181) a nakonec nedospělý jedinec (č. 101). Pozoruhodné jsou dvě výrazné koncentrace těchto hrobů, a to prímo na severním okraji nekropole, kde vytvářejí téměř souvislou řadu, a dále pak ve středové části pohřebiště, kde je jejich zřetelný shluk. Výbavu obsahovala takřka polovina těchto hrobů. Přehled orientací znázorňuje graf 6 , rozmístění opačně orientovaných hrobů plán 3.

Na rajhradickém pohřebišti se podle údajů Č. Stani podařilo objevit celkem čtyři výklenkové hroby (tj. přibližně 1,7 \% všech hrobů), a to č. 159, 143, 236 a „výklenkový dvojhrob“ 131 a, b. Nesourodé podloží na lokalitě neposkytovalo vhodné podmínky pro hloubení výklenků, ty proto nebyly nijak pravidelné (Staňa 2006, 25).

Interpretace některých hrobů jako výklenkových se však neobejde bez problémů. Popis hrobové jámy č. 159 působí značně nejistě, Č. Staňa v katalogu píše: „Podle vzhledu hrobové jámy na plánu i na fotografii lze soudit, že jde o výklenkový hrob. “ (Staňa 2006, 153). Tento hrob by také byl jediným př́padem, kdy by se na nekropoli kombinovala úprava hrobové jámy pomocí kamenů a výklenek. Kostra ženy, poněkud nakloněná do šachty, měla u hlavy a pravého ramene dva kameny, další kámen se nacházel při její pravé holeni a čtvrtý před nohama. Pozoruhodný by také byl podle Stani „výklenkový dvojhrob“ dvou mladých žen (adultus II a juvenis), kde jedna žena měla být pohřbena v hlubším výklenku na severní straně, druhá v mělčím na straně jižní (Staňa 2006, 25). Staňa popisuje 


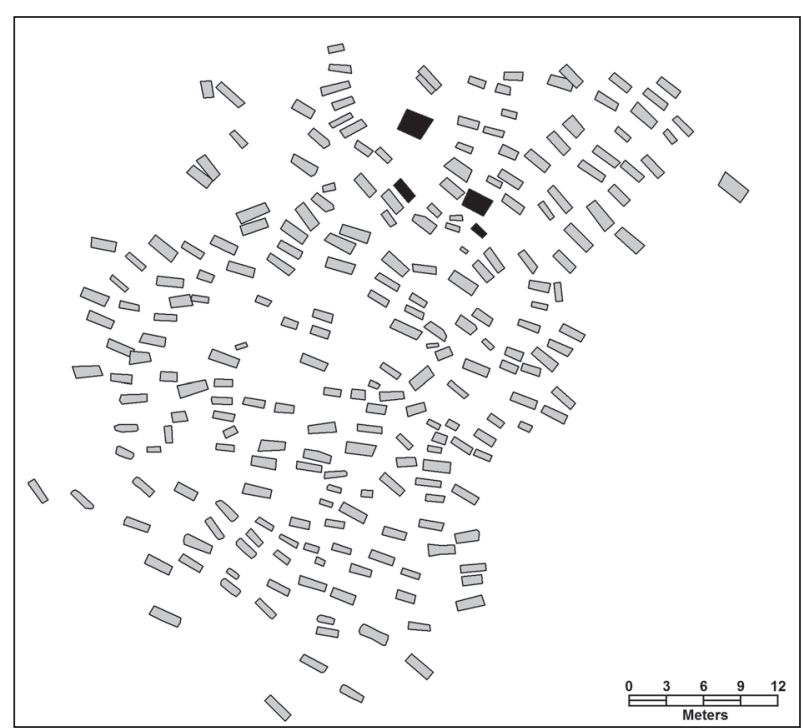

Plán 4. Výklenkové hroby. - Plan 4. Alcove graves.

nálezovou situaci takto: „Na hladině výkopu nepravidelně čtvercový půdorys. Výrazně se oddělovala stř̌ední část, hluboká jen asi $17 \mathrm{~cm}$, s černým zásypem. Ze středu se zahlubovaly do stran výklenky“ (Staňa 2006, 151). Celou situaci není jednoduché posoudit, $\mathrm{k}$ jednoznačnému závěru by bylo nutno dospět již v terénu. Na lokalitě tedy můžeme počítat jistě pouze se dvěma výklenkovými hroby, další dva patř́ $\mathrm{k}$ tomuto typu pouze hypoteticky.

Všechny čtyři př́ípadné výklenkové hroby měly obvyklou orientaci (tj. rozmezí mezi Z-V a SZ-JV). Šlo o pohřby žen věkové skupiny juvenis a adultus, v jednom prŕpadě o pohřeb dítěte (č. 236). Všechny výše zmíněné hroby neobsahovaly výbavu, ze zásypu hrobu č. 159 však pocházejí dva zdobené střepy z výduti nádoby. Výklenkové hroby se koncentrovaly blíže k severnímu okraji pohřebiště, skupinku dvou jistých a dvou hypotetických výklenkových hrobů znázorňuje plán 4.

Stupně při stěnách se v Rajhradicích objevily jen ve dvou hrobech. Šlo o hr. č. 134, kde se jáma zúžila asi v hloubce $50 \mathrm{~cm}$ a nepravidelný, 7-13 cm široký ústupek lemoval rakev z jedlového dřeva a dle Č. Stani nelze rozhodnout, byl-li vytvořen záměrně. V dvojhr. č. 239 se nepravidelné odsazení objevilo v hloubce $35 \mathrm{~cm}$ a spodní část jámy měla korytovitý tvar (Staňa 2006, 25).

Zásyp hrobů byl často nejednotný, nebot' lokalita se vyznačuje nesourodým podložím. $\mathrm{V}$ zásypu se také obvykle výrazně odlišovala výplň rakve od zbytku hrobové jámy, také zásyp výklenku měl obvykle jiný charakter než výplň jámy. Předmět v zásypu se vyskytl jen u sedmi hrobů. V hr. č. 1 šlo o zlomky pravěké keramiky, v hr. č. 52 byly nalezeny zlomky kování vědérka, v zásypech hr. č. 148, 159 a 332 se našlo po dvou zlomcích zdobené slovanské keramiky, v hr. č. 210 byly ve výplni hrobové jámy tři únětické střepy a v hr. č. 222 bronzová spirála únětického původu.

Dřevěné prvky byly identifikovány ve 123 hrobech (51,5\% všech hrobů). Toto číslo samozřejmě s nejvyšší pravděpodobností neodpovídá původní realitě. Můžeme předpokládat, že v některých hrobech dřevěné prvky zcela podlehly zkáze a do dnešních dnů se nedochovaly, avšak i tam, kde se dochovaly, mohly být během výkopových prací přehlédnuty a zničeny. Je nutné brát $\mathrm{v}$ potaz, že pracujeme s neúplnými daty a předložené přehledy chápat stále jako relativní.

Výbavu obsahovalo 72 hrobů se zachovalým dřevem (přibližně $59 \%$ z počtu hrobů se dřevem), bez výbavy bylo zbylých 51 hrobů. Šlo většinou o samostatné hroby, dvojhrob se mezi nimi vyskytl jediný (č. 148). Ve 13 případech se dřevo kombinovalo s kameny.

Věková struktura jedinců pohřbených $\mathrm{v}$ hrobech se dřevem je následující: ze 123 hrobů bylo 36 dětských, z nichž 21 mělo výbavu, 17 patřilo věkové kategorii juvenis $-10 \mathrm{z}$ nich obsahovalo výbavu, 28 hrobů se dřevem náleželo mužům ( $\mathrm{z}$ toho 20 mělo výbavu), 29 ženám (14 s výbavou) a 14 dospělým jedincům neurčeného pohlaví (z nichž 8 mělo výbavu). Věková struktura dospělých působí vyrovnaným dojmem, $\mathrm{v}$ hrobech s dřevěnými konstrukcemi se vyskytovaly jedinci věkových kategorií adultus i maturus.

Zdá se, že nemůžeme hovořit o vazbě př́tomnosti dřeva $v$ hrobě s pohlavím a věkem zemřelého. Poměr mezi zemřelými je přibližně vyrovnaný, $\mathrm{v}$ rámci jednotlivých kategorií představují jedinci pohřbení $\mathrm{v}$ těchto hrobech slabou nadpoloviční většinu, možná je však určitá preference mužủ (17 juvenis v rakvích představuje $57 \%$ všech zástupců této kategorie, 28 mužů představuje $65 \%$ všech mužů, 29 žen $52 \%$ všech žen a 14 neurčených $56 \%$ všech dospělých jedinců neurčeného pohlaví). Děti tvoří výjimku 36 dětských hrobů s dřevěnou konstrukcí představuje jen $40 \%$ všech dětských hrobů.

V 74 př́padech bylo možno stanovit rozměry schránky, které svojí velikostí odpovídaly zemřelým. Kratší než $100 \mathrm{~cm}$ byly jen dvě rakve dětí do 3 let (č. 96, 102). Celkem 32 dospělých leželo ve schránkách 180 až $200 \mathrm{~cm}$ dlouhých, muži obvykle v rakvích delších než byly rakve, které vlastnily ženy. Přes $200 \mathrm{~cm}$ měly schránky v 9 hrobech, nejdelší rakev, $225 \mathrm{~cm}$, vlastnil muž v hr. č. $323 \mathrm{~s} \mathrm{honosným} \mathrm{nákon-}$ čím. Průměrná šírka rakve se pohybovala okolo $40 \mathrm{~cm}$, stopy po dřevě se dochovaly $15-45 \mathrm{~cm}$ nad dnem hrobových jam (Staňa 2006, 29). Stopy po dřevěných konstrukcích na rajhradické nekropoli neumožňují rekonstruovat celou škálu použití. Truhly byly obvykle kvádrovitého tvaru, jindy vícestěnné, 
ojedinělá byla rakev zhotovená z kmene stromu (hr. č. 315). Jen v jednom případě byly doloženy hřebíky (hr. č. 201), ve dvou př́ípadech šlo o dřevěné obložení jámy (hr. č. 68 a 81) (Staňa 2006, 32).

Vzorky dřeva na paleobotanickou analýzu byly odebrány celkem z 36 hrobů, analýzu provedl E. Opravil. V 33 případech pocházely vzorky z jedlového dřeva (Abies alba), v hrobě $316 \mathrm{z}$ dubu, v hrobě 118 se dochoval kousek javorového dřeva (Acer sp.) a vzorek z hrobu 323 nebylo možno určit (Staňa 2006, 27-28; tabulka tamtéž). Jedle přitom v okolí Rajhradic nerostly, jejich dřevo muselo být dováženo nejspíš z Drahanské vrchoviny, jejíž okraje jsou odsud přibližně $15 \mathrm{~km}$ vzdáleny (Staňa 2006, 27).

$\mathrm{Z}$ porovnání s údaji z publikovaných moravských pohřebišt' se zdá, že rajhradická nekropole svým zastoupením dřevěných prvků v hrobech ostatní lokality převyšuje. Rajhradické nekropoli se blíží jen pohřebiště ve Velkých Bílovicích, kde dřevěnou úpravu měla téměř polovina hrobů (46,6\%). Podle některých údajů na dalších velkomoravských lokalitách nepřesahují dřevěné úpravy obvykle $15 \%$ (Měrínský 1985, 22-24), což však nejspíš zcela neodpovídá raně středověké realitě.

Kámen se objevil celkem v 21 hrobech ( $\mathrm{tj}$. přibližně $9 \%$ všech hrobů). Tyto hroby měly převážně obdélný půdorys, v jednom př́ipadě (hr. č. 159) šlo údajně o výklenkový hrob, ve 13 případech se kámen kombinoval s pozůstatky dřeva. Z těchto 21 hrobů jen 9 obsahovalo výbavu. Šlo o hroby mužů, žen, nedospělých, i dětí. V některých hrobech byl využit bílý vápencový kámen $\mathrm{z}$ únětických hrobů, jiné obsahovaly nažloutlé pískovcové kameny (Staňa 2006, 26).

$\mathrm{V}$ některých případech je velmi obtížné stanovit, zda jde o záměrné uložení nebo zda se kámen do hrobu dostal náhodou. Vzhledem k tomu, že se raně středověké pohřebiště nacházelo v místě dřívějšsího pohřebiště únětické kultury, nedá se vyloučit náhodné sekundární přemístění kamene do velkomoravského hrobu z původního obložení hrobu únětického.

Za jednoznačně úmyslné kamenné obložení můžeme považovat kameny pouze ve 4 hrobech, a to hr. č. 7, kde se na úrovni kostry zachoval kamenný obklad, dále hr. č. 40, který byl téměř celý (asi $40 \mathrm{~cm}$ nade dnem) obložen plochými kameny litavského vápence, dále hr. č. 103, kde jednu stěnu lemovalo asi 20 plochých kamenů, a pak snad hr. č. 134, který obsahoval obložení kameny kolem hlavy i nohou. Se samostatně uloženými kameny na úrovni kostry se pak můžeme setkat v 9 hrobech (č. 241, 15, 159, 166, 263, 266, 329, 88, 110).

Kámen v hr. č. 212 ležel přes hlavu a hrudník bohatě vybaveného dítěte. Kameny se také v hojnější míře vyskytly ve vrchních vrstvách zásypu hrobu č. 176, kde však při kostře žádné kameny nebyly a jejich úmyslné umístění do zásypu se jeví jako

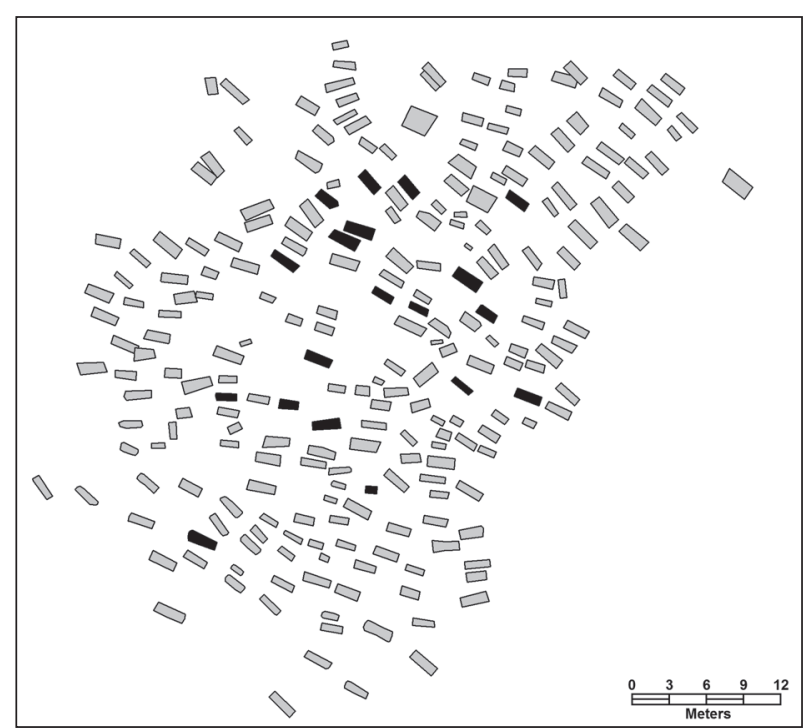

Plán 5. Hroby s kameny. - Plan 5. Graves with stones.

sporné. Ojediněle se kameny vyskytly i v 6 hrobech, u nichž je však záměrné uložení či pokus o jakýsi „systém“ problematický a jejich spojení s rituálním záměrem nejisté. Šlo z velké části o hroby pouze s jedním kamenem, v př́ípadě, kdy se kamenů objevilo více, nevytvářely žádná pravidelná uskupení. Hroby s kameny se výrazně koncentrují ve středové části pohřebiště (plán 5).

V 239 hrobech byly odkryty pozůstatky 244 jedinců. Šlo o jednotlivé hroby a pět dvojhrobů. Zachovalost koster neumožňovala v celkem 28 případech (tj. asi u 11 \% všech koster) zodpovědně určit, v jaké poloze se tělo původně nacházelo.

Na pohřebišti v Rajhradicích byli zemřelí, stejně jako na jiných raně středověkých lokalitách (Dostál 1966, 27), obvykle ukládáni na zádech s pažemi podél těla. Drobné odchylky od této základní polohy považuji ve shodě s Č. Staňou za rovněž standardní polohu (Staňa 2006, 33). Může se jednat o pokrčení paží tak, že jedna či obě ruce směřují do klína, o nepatrné natočení kostry, nachýlení lebky a podobně. Tyto výjimky mohou být zapř́ičiněny pohybem nebožtíka při přenosu v rakvi a nemusí nutně znamenat rituální odchylku. Z 216 nebožtíků, u nichž bylo možno určit polohu těla, zaujímalo standardní polohu 209 koster (tj. asi 86 \% všech zemřelých).

Od běžné polohy se odlišovalo jen sedm nebožtíků (cca $3 \%$ všech koster). Nejde však o př́liš̌ výrazné anomálie, které bychom mohli považovat za zvláštní odchylku z běžného ritu a vysvětlovat je jako výraz odlišných rituálních zvyklostí. Celkem tř̌i nedospělí jedinci (hroby č. 104, 141, 246) byli uloženi na zádech s nohama mírně pokrčenýma a vytočenýma na levou stranu. V hrobě č. 229 měl neurčený dospělý jedinec od sebe odtažená kolena a nohy tak byly mír- 
ně pokrčeny. Další 3 hroby (č. 7, 98, 295) obsahovaly kostry, jejichž ruce byly výrazně ohnuty, tj. v pravém a ostřejším úhlu. Všechny tři hroby s kostrami s výrazně ohnutýma rukama se nacházely ve středové části pohřebiště.

Avšak i některé další kosterní pozůstatky uložené standardním zpo̊sobem zasluhují pozornost. Hrob č. 310 obsahoval mladého jedince ve věku 16-18 let, jehož jinak dobře zachované kostře chyběla noha. C̆. Staňa $(2006,160)$ v katalogu píše: „Levá noha byla pod kolenem uř́ziznutá, kosti v hrobě chyběly." Pozorování není možno v současné době ověřit vzhledem k tomu, že výsledky antropologického průzkumu nebyly publikovány. Hrob byl poměrně bohatě vybaven; obsahoval stř́ibrnou bubínkovou náušnici, další zlomky bronzových náušnic, zlomek stříbrné náušnice a pozůstatky dvou nožů. Mohlo by se jednat o doklad zranění, nebot' náušnice jsou uloženy mimo svoji funkční polohu v místě, kde kosti končí.

Zajímavý je také hr. č. $212 \mathrm{~s}$ pozůstatky dítěte ve věku 4 až 5 let. Dítě leželo v rakvi a bylo bohatě vybaveno, mělo při sobě 2 nože a ostruhy s průvlečkami a přezkami. Chlapec ležel ve standardní poloze na zádech, s běžnou orientací $\left(300^{\circ}\right)$, avšak přes tvář a částečně hrud' měl položen velký kámen. Podle Z. Krumphanzlové (1961, 546) souvisí zatížení nebožtíka kameny jednoznačně s vírou v návrat mrtvého ze záhrobí. Možnost, že v tomto př́padě jde o opatření proti revenantovi, nelze samozřejmě vyloučit, avšak jsou možné i jiné varianty výkladu. Chlapec byl v měřítku lokality bohatě vybaven, což neodpovídá pozorování, že „nerituální“ pohřby bývají vybaveny málo nebo skromně (Krumphanzlová 1961, 548). Byl pohřben v rakvi, takže se domnívám, že je přípustná možnost propadnutí kamene, původně uloženého na víku rakve, po uhnití dřeva na tělo zemřelého.

Z běžného ritu se také vymykají výše popsané opačně orientované hroby. Šlo o 17 hrobů, z nichž převážná většina patřila dětem, opačně bylo také orientováno dítě v dvojhrobě 239, hroby byly bez výbavy i s výbavou a na pohřebišti zaujímaly dvě výrazné koncentrace. Převaha obrácených dětských hrobů oproti jiným populačním skupinám je relativně běžná ( ̌́tefan 2009, 148-149).

Na pohřebišti v Rajhradicích bylo objeveno celkem 5 dvojhrobů, které představují $2 \%$ celkového počtu hrobů. Šlo o hr. č. 39, 85, 131, 148 a 239. Šlo o pohřby žen a dětí, popř. neurčeného jedince, muž se v dvojhrobě nevyskytl. Dvojhroby byly jak s výbavou, tak bez ní.

Hrob č. 39 obsahoval pozůstatky dvou shodně orientovaných dětí (infans I a II), v hr. č. 85 spočinul dospělý neurčený jedinec s dítětem. Obě kostry ležely shodně orientované (azimut $295^{\circ}$ ), těsně u sebe, dětská kostra vlevo od dospělé. Patrně dvojhrob č. 131 obsahoval pozůstatky dvou mladých žen (juvenis a adultus), obě byly stejně orientované $\left(291^{\circ}\right)$. V hr. č. 148 byly objeveny dvě dětské kostry (infans I a II), shodně orientované $\left(308^{\circ}\right)$, obě děti ležely v jedné rakvi. Hrob č. 239 patřil ženě věkové kategorie maturus I, která byla pohřbena spolu s dítětem ve věku 4 až 5 let. Dítě, ležící u nohou ženské kostry, bylo oproti ženě opačně orientováno (žena $315^{\circ}$, dítě $135^{\circ}$ ). Jáma se v hloubce $105 \mathrm{~cm}$ zúžila a na schůdku ležela zdobená nádoba s keramickou značkou na dně.

\section{Hrobová výbava}

Na rajhradickém pohřebišti obsahovalo archeologicky doložitelnou výbavu celkem 129 hrobů (tj. 54 \% všech hrobů na nekropoli), bez př́ídavku bylo 110 hrobů (46 \% všech hrobů; viz plán 6). Celkem bylo vybavených 130 jedinců. Šlo o 28 žen (50\% všech žen), 31 mužů (72 \% všech mužů), 14 dospělých jedinců neurčeného pohlaví (tj. 56 \%), 14 jedinců věkové kategorie juvenis (47\%) a 43 dětí (přibližně $48 \%$ všech dětí). Mezi 110 hroby, které neobsahovaly žádné př́ídavky, se objevily 2 dvojhroby, nevybavených tedy bylo celkem 114 nebožtíků, a to 28 žen (tedy 50 \% všech žen na pohřebišti), 12 mužů (28 \% všech mužů), 11 dospělých neurčeného pohlaví, 16 jedinců skupiny juvenis (53\% všech jedinců této kategorie) a 47 dětí (tj. $52 \%$ všech dětí). Rozvrstvení jedinců (s výbavou i bez výbavy) do věkových kategorií ukazují grafy 7,8 a 9 ).

Zároveň je nutné brát ohled na skutečnost, že pracujeme s archeologicky doloženou výbavou. Před-

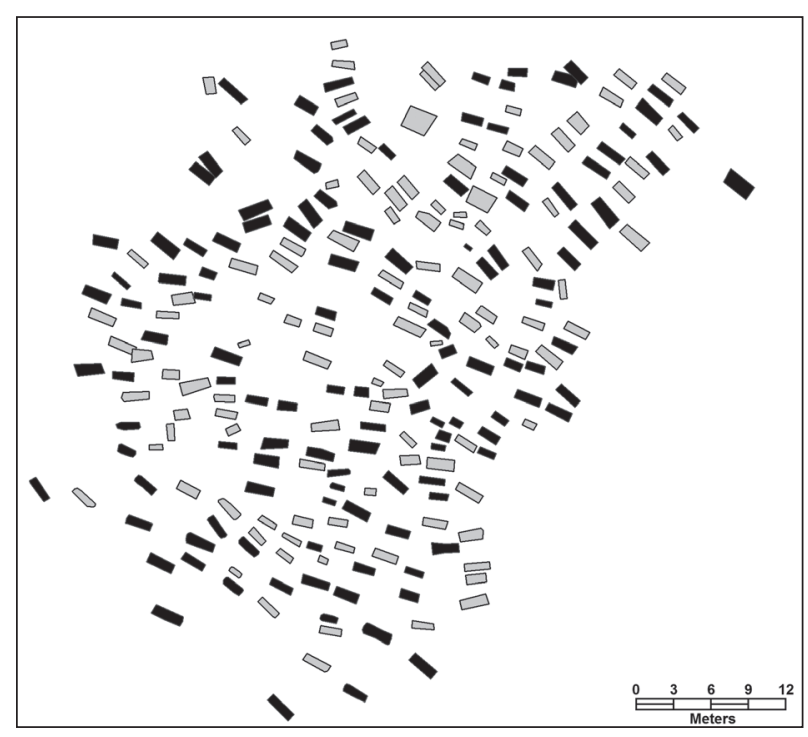

Plán 6. Hroby s výbavou. - Plan 6. Graves with grave goods. 


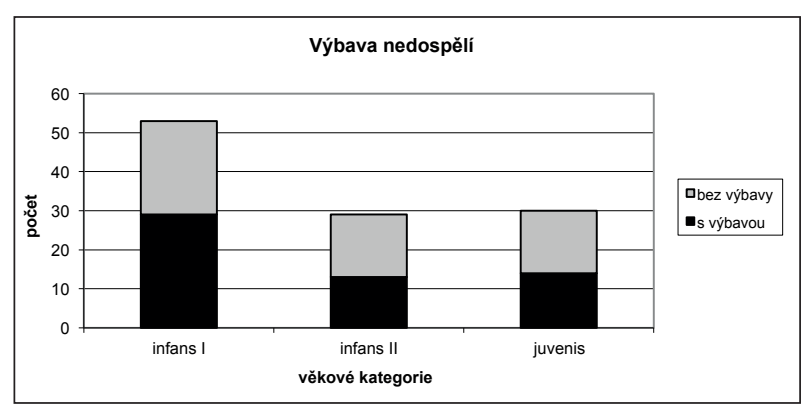

Graf 7. Hrobová výbava nedospělých jedinců. - Graph 7. Grave goods of juvenile individuals.

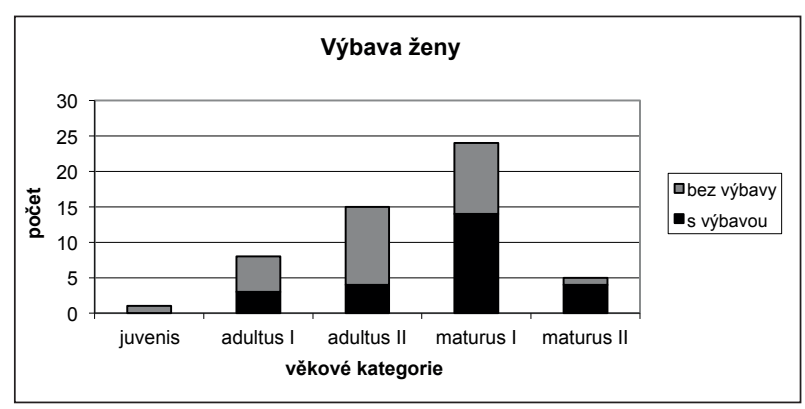

Graf 9. Vybavenost ženských hrobů. - Graph 9. Grave goods in female graves.

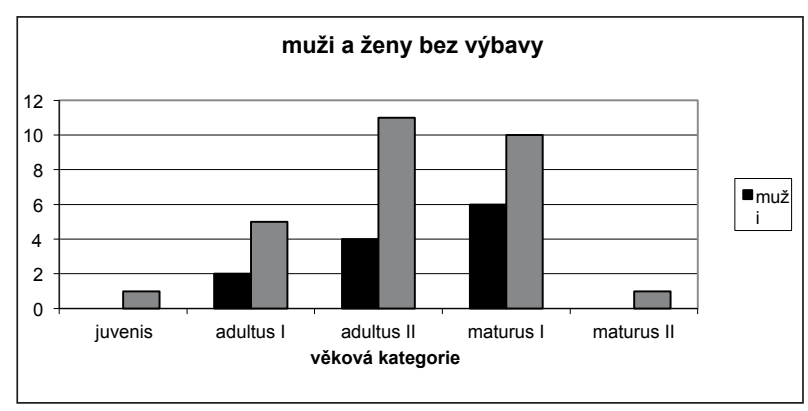

Graf 11. Nevybavení muži a ženy dle věku. - Graph 11. Men and women with no grave goods according to age.

měty $\mathrm{z}$ organických materiálů se $\mathrm{z}$ drtivé většiny nedochovaly, a proto se mezi zdánlivě nevybavenými hroby nejspíš skrývají hroby, které původně nějak vybaveny byly. Veškeré závěry je proto třeba chápat jako relativní, a to ze samé podstaty archeologických pramenů.

Z výše uvedených počtů vybavených a nevybavených jedinců se zdá, že kromě mužů byla vybavena vždy přibližně polovina jedinců př́íslušné skupiny. Nemůžeme sledovat ani nijak výraznou preferenci určité věkové kategorie, snad jen u žen se může zdát, že př́ídavky byly ukládány spíše do hrobů starších žen. Většina mužských hrobů př́davky obsahuje a jen malý podíl mužských hrobů je zcela bez nálezu (graf 10 a 11). Z grafů vyplývá vyšší zastoupení

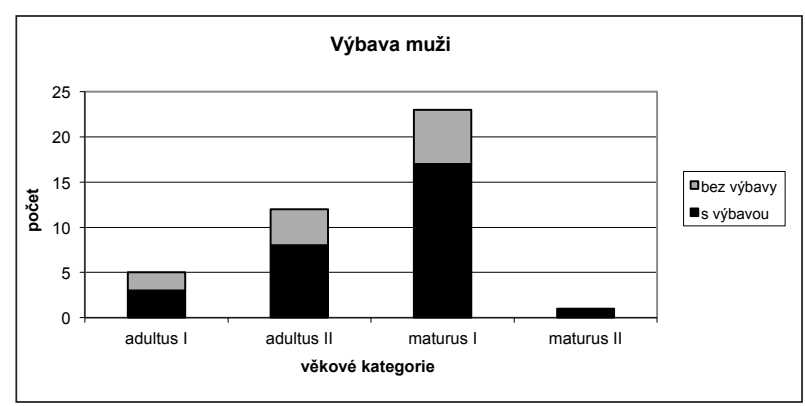

Graf 8. Vybavenost mužských hrobů. - Graph 8. Grave goods in male graves.

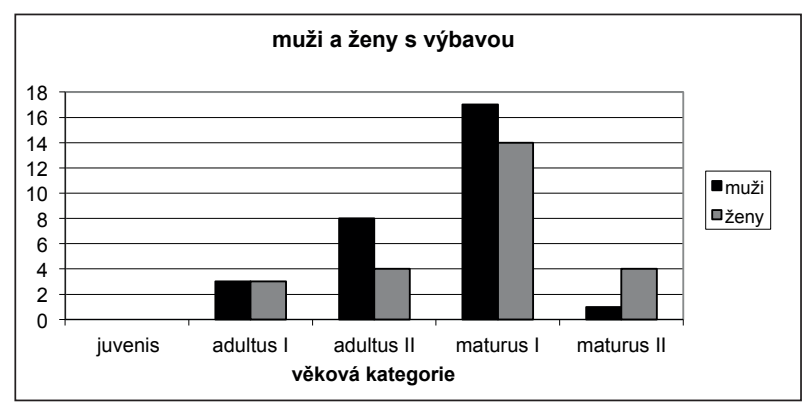

Graf 10. Vybavenost mužů a žen podle věku. - Graph 10. Grave goods of men and women according to age.

výbavy u mužských pohřbů než u žen. Pracuji však s nižším objemem dat, který nepřináší dostatečně reprezentativní výsledky.

Následující přehled inventáře nemá v žádném případě suplovat již publikovaný katalog, který obsahuje podrobné popisy předmětů. Kombinace předmětů $\mathrm{v}$ hrobech ukazuje připojená kombinační tabulka.

\section{Šperky a součásti oděvu}

Na rajhradickém pohřebišti se vyskytují ve 42 hrobech (17,6\% všech hrobů na pohřebišti). Šlo o hroby žen, dětí i nedospělých jedinců. Na nekropoli se vyskytoval šperk podunajského typu, veligradský šperk, prsteny, gombíky, rolničky i korálky. Při určování jednotlivých typů šperků se opírám o systém zavedený $\check{S}$. Ungermanem (2005).

Náušnice podunajského typu se vyskytly v zastoupení 31 kusů v 16 hrobech, z toho bylo devět hrobů dětí, čtyři nedospělých jedinců a tři žen věkové kategorie adultus I (dva př́pady) a neurčeného stárí. Šperk je rozptýlen po celé ploše pohřebiště bez náznaku prostorové koncentrace. Náušnice se obvykle nacházely u hlavy zemřelé, jen výjimečně u pasu (4 kusy v dvojhr. č. 148, 1 kus v hrobě 157) či u levé nohy (2 kusy v hr. č. 310$)$.

Typ 7-1, tedy jednoduché kroužkovitén náušnice, se objevil v zastoupení čtyř kusů v dětském hrobě číslo 100. 


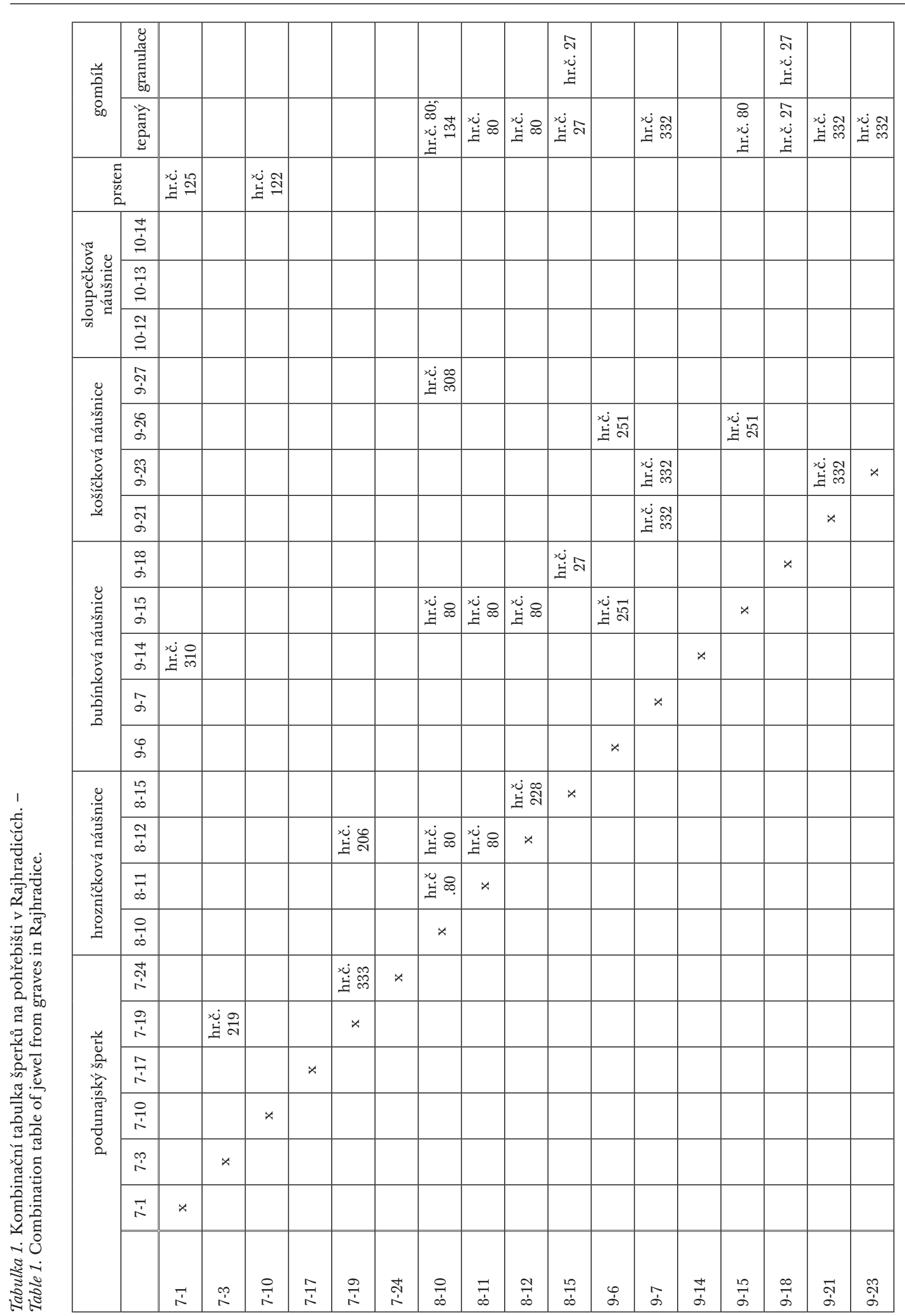




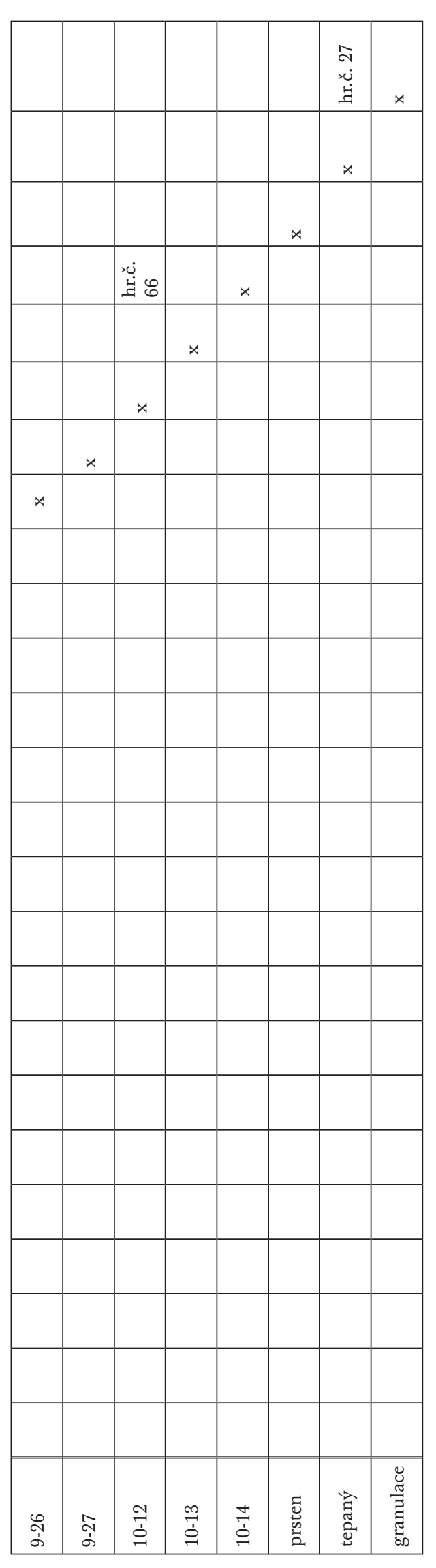


Dva jednoduché kroužky byly vyrobeny z bronzu, dva ze stř́bra, nacházely se po dvojicích na každé straně lebky. K tomuto typu mohly náležet i zlomky dvou bronzových náušnic z dětského hrobu č. 125 a z hrobu č. 310 patřícímu jedinci věkové kategorie juvenis.

Typ 7-3, tedy náušnice se dvěma uzlíky ze silnějšího drátu, se vyskytl v počtu 5 kusů z 3 hrobů (hr. č. 95, 157, 219). Všechny náušnice byly bronzové.

Typ 7-10, náušnice se spirálovitým válečkovitým ukončením, se vyskytl v počtu dvou kusů ve dvou hrobech. Jedna náušnice pochází z ženského hrobu č. 122, bronzová náušnice je ve dvou zlomcích. Druhý, avšak neúplný kus se našel v dvojhr. č. 239 při kostře dítěte.

Typ 7-17, tedy náušnice s oboustranným spirálovitým závěskem, byl zastoupen dvěma kusy z dětských hr. č. 148 a 320. Stř́ibrná náušnice z hrobu č. 148 měla hraněný oblouček a oboustranný závěsek z filigránního drátku, náušnice z hrobu č. 320 byla bronzová, s neúplným obloukem.

Typ 7-19, tedy náušnice s plechovým závěskem, se na pohřebišti objevil v 11 kusech v 8 hrobech (hr. č. 47, 135, 148, 206, 213, 219, 295 a 333). Všechny exempláře byly vyrobeny z bronzu. V hrobech č. 47, 135 a 333 se objevily ve variantě s obloukem ukončeným kličkou či očkem. V hr. č. 148 byla jedna ze dvou náušnic $\mathrm{v}$ torzovitém stavu a její příslušnost $\mathrm{k}$ tomuto typu je pouze hypotetická.

Typ 7-24, náušnice se dvěma nezdobenými bubínky po stranách, je zastoupen jedním kusem z ženského hrobu č. 333.

Zvláštní typy představují dva kusy náušnice $\mathrm{z}$ hrobu č. 95, které měly na hraněném oblouku s uzlíky zavěšen oboustranný plechový válcovitý dvakrát př́ičně zaškrcený závěsek, v jednom případě s kuličkou. Dle Š. Ungermana $(2007,207)$ jde o imitaci typu 7-17.

Hrozníčková náušnice se vyskytla $v$ počtu 29 kusů v 12 hrobech. Šlo o hroby dětí (sedm hrobů) a žen (celkem pět, věková kategorie maturus). Hroby s hrozníčkovými náušnicemi vytvářely v zásadě 3 menší skupinky po čtyřech hrobech při JZ, SV a S okraji pohřebiště. Další dva hroby byly rozptýleny při jižním okraji nekropole. Všechny náušnice byly vyrobeny ze stříbra a v naprosté většině případů se nacházely u hlavy zemřelé, výjimečně u pasu (dvojhrob 148), u pravé paže (ženský hrob 27) či u levé nohy (hrob 310).

Typ 8-10, tedy náušnice s oboustranným klasovitým hrozníčkem a nezdobeným obloukem, se vyskytl v 15 exemplářích, které pocházely ze šesti hrobů (č. 80, 106, 108, 134, 141 a 308). V hrobech č. 80, 106, 108,141 se vyskytly i varianty s hraněným obloukem.

Typ 8-11, náušnice s oboustranným hrozníčkem a nezdobeným obloukem zakončeným očkem, se objevil v zastoupení dvou kusů ve dvou hrobech (hr. č. 80, 97).
Typ 8-12, tedy náušnice s oboustranným hrozníčkem a nezdobeným obloukem zakončeným kličkou, obsahovaly v počtu pěti kusů tři hroby (hr. č. 80, 206 a 228).

Typ 8-15, náušnice s granulací zdobeným spodním obloukem, je zastoupen pěti kusy ze tří hrobů (hr. č. 27, 210, 228). V hr. č. 210 se objevila varianta s hraněným obloukem.

Některé hrozníčkové náušnice není možno blíže zařadit do typologie podle Dostála (1966). Jde o dva kusy z hr. č. 80 a 147 . V hr. č. 80 z jedné pravděpodobně hrozníčkové náušnice zbyl pouze oblouček s granulovaným uzlíkem, další neidentifikovatelné zlomky hrozníčkové náušnice a druhé, snad s ní tvořící pár, se objevily v hr. č. 147.

Bubínková náušnice je zastoupena 10 kusy v pěti hrobech. Šlo o dva dětské hroby, jeden hrob nedospělého jedince, jeden ženský a jeden hrob dospělého jedince neurčeného pohlaví. Všechny náušnice byly stř́ibrné a kromě náušnic z hr. č. 27 se nacházely u hlavy; v hr. č. 27 byly uloženy u pravé paže. Bubínkové náušnice byly rozptýleny při J a Z okraji pohřebiště.

Typ 9-6, tedy náušnice se čtyřmi bubínky a spodním obloukem lemovaným filigránozými drátky, představují 2 kusy v hr. č. 251.

Typ 9-7, se čtyřmi bubínky a granulovaným spodním obloukem, reprezentují dva kusy z hr. č. 332.

Typ 9-14, tedy náušnice se sedmi bubínky zdobenými motivem trojúhelníki, se objevil pouze jednou, a to v hr. č. 310.

Typ 9-15 se sedmi bubinky s motivem kosočtvercù č $i$ kosodélníku je zastoupen třemi kusy v hr. č. 80 a 251.

Typ 9-18 sosmi bubínky se objevil v počtu dvou kusů v hr. č. 27.

Košíčkové náušnice byly objeveny v počtu devíti kusů ve třech hrobech. Šlo o hrob dítěte, ženy a dospělého jedince neurčeného pohlaví. Všechny náušnice byly stř́ibrné a vyskytovaly se u hlavy zemřelých. Všechny tři hroby se nacházely při J okraji pohřebiště.

Typ 9-21, náušnice se sedmi košíčky, je zastoupen dvěma kusy z dětského hr. č. 332. Obě se dochovaly pouze torzovitě.

Typ 9-23, náušnice s devíti košíčky, reprezentují tři kusy z hr. č. 332. Žádná z těchto náušnic se nedochovala $\mathrm{v}$ úplnosti.

K typu 9-26 se šesti košíčky náleží patrně košíčková náušnice $\mathrm{z}$ hr. č. 251. Náušnice je neúplná, její přiřazení k tomuto typu je hypotetické.

Typ 9-27 se čtyrmi košičky se podařilo objevit v počtu dvou kusů v hr. č. 308. Spodní oblouk je zdoben filigránními drátky.

Jeden kus košíčkové náušnice z hr. č. 332 je v natolik torzovitém stavu, že jeho typové zařazení nebylo možné. 
Sloupečkové náušnice se vyskytly v počtu pěti kusů ve dvou hrobech (hr. č. 156 a 66). Šlo o hrob dítěte a ženy neurčeného věku. Ve třech př́ípadech byla náušnice vyrobena z bronzu (hr. č. 156 a 2 kusy v hr. č. 66), dvakrát ze stř́bra (hr. č. 66), v obou hrobech ležela u hlavy zemřelé. Jeden hrob se nacházel při severním okraji pohřebiště, druhý při jižním.

Typ 10-12, náušnice s granulovanými kř́žky a obloukem ukončeným kličkou, je zastoupen 2 kusy v hr. č. 66 .

Typ 10-13, náušnice zdobená kroužky z hladkého drátu se spodním obloukem zakončeným několikanásobnými uzlíky, se objevil v dětském hr. č. 156. Bronzová pozlacená náušnice se dochovala v torzovitém stavu.

Typ 10-14, tedy náušnice zdobená kroužky z hladkého drátu s obloukem ukončeným kličkou, se vyskytl v zastoupení 2 kusů v hr. č. 66. Náušnice byly vyrobeny z bronzu a postríbřeny.

Prsteny se objevily v počtu tří kusů v 3 hrobech. Šlo o hroby dětí (hr. č. 125 a 167) a ženy věkové kategorie adultus (hr. č. 122). Všechny byly vyrobeny z bronzu a spočívaly na pravé ruce nebožtíka. Šlo výhradně o prsteny se štítkem zdobeným vybíjeným ornamentem.

Gombíky jsou zastoupeny 20 kusy z 11 hrobů. Převážně šlo o hroby dětí (osm hrobů), další tři hroby patřily ženám věkové kategorie adultus (hr. č. 31) a maturus (hr. č. 27 a 134). Z velké části byly stř́ibrné, jen sedm kusů bylo vyrobeno z bronzu. Nacházely se v horní části trupu či u hlavy. Hroby s gombíky se soustředily ve středové části nekropole.

Gombíky zdobené tepanými ornamenty se objevily v počtu 16 kusů v hr. č. 27, 31, 80, 96, 112, 114, 134, 266 a 332. Z velké části byly vyrobeny ze stříbra, někdy zlaceného (hr. č. 266, 332), čtyři kusy byly bronzové zlacené (hr. č. 112, 114). Rozměry tepaných gombíků se pohybovaly mezi 2 až $5 \mathrm{~cm}$.

Gombík s granulovanou výzdobou se vyskytl v jediném exempláři v hr. č. 27 společně se stř́brným tepaným gombíkem. Byl vyroben ze stř́ibra a silně pozlacen, zdobený svislými granulovanými pásy.

V hr. č. 119 se objevil polyedrický gombík. Gombík je vyroben ze zlaceného bronzu, s modrou polokulovitou skleněnou vložkou na spodku, kolem níž jsou 4 kapkovité přihrádky pro další skleněné vložky; ve dvou přihrádkách jsou dochovaná modrá skla, ze dvou vložky vypadly.

V hr. č. 108 byly nalezeny zlomky dva bronzových gombíků, jejichž povrch je natolik poškozen patinou, že výzdobu není možné určit.

Gombíkům se ve své práci věnovala např. H. Chorvátová (2008), která vyloučila funkci gombíků jako spínadel oděvu. Domnívá se, že gombíky mohly být našívány na ozdobné lemy tunik, popř. nošeny jako součást náhrdelníku, a jejich výskyt spojuje s elitou. Vzhledem k tomu, že se často objevují v dětských hrobech, mohou symbolizovat dědičnou př́slušnost těchto dětí $\mathrm{k}$ vyšší sociální vrstvě a současně představovat amulet se symbolikou nesmrtelnosti či věčného života (Chorvátová 2008, 212-215).

Rolničky jsou na pohřebišti zastoupeny dva kusy ze dvou dětských hrobů (hr. č. 82 a 327). Oba hroby ležely blíže k jižnímu okraji pohřebiště. Rolničky, ochranný předmět s funkcí zahánění zlých duchů zvukem (Smetánka 1993), se nacházely u pasu dítěte. V obou případech byla rolnička vyrobena ze železa, v hr. č. 82 měla rolnička kruhové plechové ouško a obvodový šev, uvnitř byly drobné kamínky. Rolnička byla obalena tkaninou a v hrobě byl spolu s ní i miniaturní nožík. V hr. č. 327 byla rolnička nalezena ve zlomcích a na jednom zlomku byl patrný spoj obou polokoulí.

Korálky byly nalezeny v počtu 30 kusů v pěti hrobech. Šlo o hroby dětí (hr. č. 125, 206, 332), ženy (hr. č. 103) a muže (hr. č. 317) věkové kategorie maturus. Hroby s korálky se nacházely v hrobech po celé ploše pohřebiště. Korálky se objevily u hlavy (hr. č. 103, 125, 317), na trupu (hr. č. 206, 332) a mezi nohama zemřelého (hr. č. 332). V naprosté většině šlo o korálky skleněné, jen v hr. č. 103 se objevil jeden korálek snad hliněný, dnes ztracený.

Podélně členěné korálky se objevily v počtu 5 kusů v dětském hr. č. 332. Korály mají olivovitý tvar, členěny jsou čtyřmi rýhami, které na korálu vytváří čtyři podélná žebra. Jeden z korálů je přepůlen. Čtyři celé korály jsou z průsvitného skla, největší má špinavě bílou barvu místy se zeleným odstínem, další tři jsou zelené. Polovina korálu je z neprůsvitné, matné, tmavě hnědé sklovité hmoty. $\mathrm{V}$ hrobě se vyskytly společně s miniaturními korálky soudečkovitého a kotoučkovitého tvaru.

Korálek olivovitý hladký je reprezentován jedním kusem z ženského hr. č. 103. Korálek měl oblý, mírně dvojkonický tvar, barva je šedohnědá.

Př́čně členěné korálky jsou zastoupeny 2 kusy v dětských hr. č. 125 a 206 . V hr. č. 125 se objevil korálek členěný dvěma příčnými rýhami, který jej dělí na tři části, je stř́ibřité barvy a kruhovitého průřezu. V hr. č. 206 se objevil dvojdílný korálek.

Kotoučkovité jednobarevné korálky se objevily v počtu 19 kusů ve dvou dětských hr. č. 206 a 332. V hr. č. 206 šlo o pět korálů kotoučkovitého tvaru o průměru $0,8 \mathrm{~cm}$ (1 kus), a $0,4 \mathrm{~cm}$ (4 kusy). Tvořily součást náhrdelníku s dvěma příčně členěnými korály - dvojitým a korálem s plastickou šroubovicí. Celkem 14 miniaturních korálků se podařilo objevit v hr. č. 332. Mimo ně se v hrobě vyskytovaly také korály podélně členěné.

V hr. č. 206 byl nalezen korál s plastickou šroubovicí, která korál př́ičně člení na několik částí. Korál měl hnědou barvu a v hrobě byl společně s dvojitým 
korálkem, který byl dlouhý 1,2 cm se stř́ibřitým povrchem, a s korálky kotoučkovitého tvaru.

Na pohřebišti se vyskytl také korálek údajně hliněný (v hr. č. 103). Korálek je dnes ztracený, vyskytoval se spolu s olivovitým hladkým korálem.

Do zvláštní kategorie patří korál z mužského hrobu č. 317. Korál se nacházel za lebkou zemřelého, je dlouhý 3,25 cm, z průsvitného zeleného skla, tvaru komolého kužele, zdobený př́ínnými esovitě prohnutými bílými pruhy vtaveného skla.

Zbraně a součásti výstroje se objevily ve 24 hrobech (10 \% všech hrobů). Šlo o hroby mužů, dospělých jedinců neurčeného pohlaví, dětí, jedinců kategorie juvenis a v jednom případě (hr. č. 201) byla kostra antropologicky určena jako ženská.

Meč je na lokalitě reprezentován dvěma kusy z hr. č. 71 a 316 (antropologicky neurčený dospělý jedinec a muž věkové kategorie adultus). Oba hroby se nacházely při jižním okraji pohřebiště. V hr. č. 71 ležel meč u pasu zemřelého, jde o Petersenův typ Y, čepel je na obou stranách členěna podélným žlábkem. Meč je dlouhý $87,5 \mathrm{~cm}$, z toho čepel $73,5 \mathrm{~cm}$. Meč byl v dřevěné pochvě potažené tenkým železným plechem, spolu s ním se v hrobě vyskytly ostruhy, kování opasku a nůž. Hr. č. 316 obsahoval meč silně poškozený korozí, bez př́ičky a hlavice, takže jeho typové zařazení není možné. Ležel podél levé nohy zemřelého, levá ruka pak spočívala při vrchním konci meče. Hrob byl vybaven také ostruhami, kováními s přezkami a nožem.

Meč typu Y je ve velkomoravském prostředí velmi vzácný. Kromě Rajhradic se objevil jen ve Vranovicích, okr. Břeclav (Galuška 2001) a hlavice tohoto typu se našla v sídlištním kontextu v Mikulčicích (Košta 2004, 16-19). Naopak v Čechách je tento typ meče nejčastější (Košta 2004, 87). Meč typu Y pochází z Roztok-Žalova, libické akropole i z polohy Kánín, z Litoměřic-Starých Šancí, Libkovic a meče tohoto typu jsou uloženy také ve sbírkách hradu Křivoklátu a v muzeu v Teplicích bez udání místa původu (Košta 2004, 15-16).

Kopí se objevilo jen v jednom hrobě (hr. č. 111). Leželo u hlavy dospělého jedince antropologem neurčeného věku a pohlaví. Tulej zaujímá přibližně třetinu délky kopí a je od listu výrazně odsazena (typ III B podle Ruttkay 1976, 299-301). Hrob se nacházel na východním okraji pohřebiště.

Sekera se na nekropoli našla v zastoupení šesti kusů v hrobech mužů kategorie adultus a maturus (hr. č. 314, 315), neurčeného dospělého jedince věkové kategorie adultus (hr. č. 26), nedospělého jedince ve věku 16 až 18 let (hr. č. 208), dítěte (hr. č. 112) ve věku 4 až 5 let a v jednom př́ípadě (hr. č. 201) šlo o špatně dochovanou kostru, která byla antropologicky určena jako žena. Čtyři hroby se sekerami se nacházely v severní polovině pohřebištěe, zbylé dva naopak na jižním okraji nekropole. Celkem čtyři sekery představují bradatice, další dvě pak patří k typu seker s protáhlým ostrím.

Typ I B (podle Dostál 1966, 70) reprezentují dva kusy z hr. č. 112 a 201. Obě sekery se nacházely při pravé noze ve výši kolene kostry, ostř́m směrem ven z hrobové jámy. Sekera z hrobu č. 201 se nedochovala, známá je pouze z popisu.

Typ I c (tamtéz) je zastoupen jedním kusem z mužského hr. č. 314. V násadním otvoru sekery se objevily zbytky dřeva a na plošce břitu zbytky řídkého gázovitého plátna. Sekera se nacházela při pravém kyčelním kloubu na vnitřní straně nohy.

Bradatice reprezentuje také sekera z hr. č. 26, která je však v natolik torzovitém stavu, že není možné ji blíže typově zařadit. Sekerka ležela při pravé stehenní kosti zemřelého, ostř́ směřovalo k chodidlům.

Typ III, tj. sekera s protáhlým ostřím (Dostál 1066, 71), byla objevena v hr. č. 208 a 315 . V hr. č. 208 jde o variantu B s protáhlým týlem, sekera nacházela při levé noze, ostří směřovalo $\mathrm{k}$ tělu, v hr. č. 315 ležela sekera při pravé noze a topůrko zřejmě mířilo do dlaně.

Šipky jsou zastoupeny pouze dvěma kusy v hr. č. 155 a 314 . V obou případech šlo o hroby mužů věkové kategorie maturus. Hroby se nacházely každý na opačném okraji pohřebiště; hr. č. 155 při severním, hr. č. 314 při jižním. V jednom př́ípadě jde o šipku s tulejkou, v druhém o rombickou šipku.

Torzovitě zachovaná šipka z hrobu č. 314 patří patrně do skupiny A:7 (podle Ruttkay 1976, 329). Šipka se nacházela u pasu zemřelého, vně jeho pravé ruky.

Rombická šipka z hrobu č. 155 patří k typu $B: 2 a$ (podle Ruttkay 1976, 330; šipka odpovídá definici typu, tvar je však poněkud jiný. Šipka ležela při hlavě zemřelého.

Ostruhy se objevily v celkovém počtu 32 kusů v 17 hrobech. Šlo o hroby mužů věkové kategorie adultus (hr. č. 52, 53, 54, 60, 124, 248, 315 a 316) a maturus (hr. č. 1, 73, 193 a 317), muže neurčeného věku (hr. č. 301), dospělé jedince neurčeného pohlaví (hr. č. 71, 229), jedince věkové kategorie juvenis (hr. č. 235) a dětský hr. č. 212. V naprosté většině byly ostruhy v hrobě v páru, jen v hrobech č. 54 a 235 se našlo jen po jedné ostruze. Ležely obvykle ve funkční poloze u nohou nebožtíka. Výjimkami jsou hr. č. 73, kde jedna ležela mezi stehenními kostmi mrtvého a druhá při stěně hrobové jámy v úrovni levé ruky. Hrob však byl značně protkán norami, které s největší pravděpodobností polohu předmětů změnily. V hr. č. 229 se jedna z ostruh, která snad původně ležela u levé nohy, objevila u stehenní kosti pravé nohy. Je otázkou, do jaké míry to souvisí se zvláštní polohou těla zemřelého, který měl obě nohy pokrčené a odtažené koleny od sebe. V hr. č. 235 ležela ostruha vně pravé nohy, blíže ke stěně hrobové 
jámy. Na pohřebišti se nacházejí v podstatě dvě koncentrace hrobů s ostruhami, a to 11 hrobů se nachází v severní části pohřebiště, dalších šest hrobů vytváří nepravidelný oblouk při jižním kraji nekropole. V̌sechny ostruhy byly vyrobeny ze železa.

Téměř výhradním typem ostruh na lokalitě byly ostruhy s řadou nýtů př́ćnou k rameni (typ IV, viz Bialeková 1977, 131-134). Ostruhy, které je možno zařadit do této kategorie, se objevily v hrobech č. $1,53,54$, 73, 212, 229, 301, 315, 316, 317 a snad i 193.

Typ ostruh s prodlouženým bodcem se objevil ve 3 hrobech, a to v hr. č. 52, 60 a 248.

Další ostruhy nebylo možno vzhledem k jejich torzovitosti spolehlivě typově zařadit. Jen malé zlomky ostruh obsahovaly hr. č. 124, 235 a bohatý hr. č. 71 .

$\mathrm{Na}$ lokalitě tedy evidujme pouze ostruhy s nýty zasazenými příčně $\mathrm{k}$ rameni, a to s krátkým i prodlouženým bodcem. Ostruhy s nýty umístěnými podélně s ramenem či páskové ostruhy, pokud to bylo možno určit, se na pohřebišti nevyskytly ani jednou.

Kování a součásti řemenů se dají rozdělit do dvou kategorií, a to na kování, která souvisejí s opaskem, a kování související s ostruhami. Různá kování a součásti řemenů, tj. přezky, průvlečky a nákončí, se našly celkem v 16 hrobech. Obvykle souvisely s ostruhami a zbraněmi, proto se opět nacházejí zejména $\mathrm{v}$ hrobech mužů, méně často v hrobech nedospělých jedinců. Jejich umístění v hrobě snad většinou odpovídá funkční poloze kování, jak se nosilo v živé kultuře.

Kování související s ostruhami se našla v 9 hrobech (hr. č. 1, 53, 193, 212, 248, 301, 315, 316 a 317). Šlo o hroby mužů věkových kategorií adultus i maturus, v jednom př́padě o dětský hr. č. 212. Šlo o oválné přezky v různém stupni dochování (v hr. č. 193, 212, $301,315,316,317)$, obdélníkové průvlečky (hr. č. 1, 53, 193, 212, 248, 301, 315, 316, 317) a obdélná nákončí s dvěma či třemi nýty (v hr. č. 1, 193, 212, 248, 316). V̌̌echna kování, která se našla společně s ostruhami, byla vyrobena ze železa.

Kování související s opaskem byla identifikována v pěti hrobech (hr. č. 18, 54, 71, 235 a 323). Šlo o hroby mužů věkových kategorií adultus i maturus, dospělého jedince neurčeného věku a pohlaví (hr. č. 71) a jedince ve věku 14 až 15 let (hr. č. 235). V hr. č. 18 se našly pozůstatky železné přezky, která snad souvisí s opaskem, na němž byl připevněn nůž. Hr. č. 54 obsahoval soupravu kování, která byla analogická té, která v hr. č. 71 doprovázela meč. Šlo o 7,4 cm dlouhé kování s průvlečkou, 2 obdélná nákončí a dvojdílné kování dlouhé $6,8 \mathrm{~cm}$. Všechna kování byla zdobena plastickou rozetou. Na takto zdobeném opasku byl však oproti hr. č. 71 zavěšen pouze nůž. V hr. č. 71 bylo nalezeno oválné, podélně prohnuté železné kování s dvěma žlábky s nýty, dále železné kování s průvlečkou, sestávající z čtvercové plotén- ky s otvory pro nýty, krátkého krčku a z elipsovitého poutka, a nakonec obdélníkové kování s otvory pro nýty v příčném žlábku. Kování z obou hrobů zařadil Š. Ungerman k typu Závada (Ungerman 2011, 584-586, 599). V hr. č. 235 se spolu s nožem objevilo drobné železné kování uprostřed obloukovitě prohnuté s háčkem na jednom konci. Nejvýznamnější nález poskytl hr. č. 323, který obsahoval luxusní bronzové nákončí a bronzovou přezku. Nákončí bylo obdélníkové, na lícní straně zdobené listy ve třech polích, která jsou rozdělena kř́ížem, nad nímž je vyryto písmeno „chí“ (Staňa 2006, 162). Rub je hladký. Nákončí bylo na řemen uchyceno třemi nýty. Přezka byla obdélníková s trojúhelníkovým trnem a týlní destičkou se dvěma nýty. Na takto zdobeném opasku byl uchycen nůž, jiný nález nebyl v hrobě objeven. Nákončí je zdobeno křestanskými motivy stromu života a stavby, kříz uprostřed je pak součástí obou motivů, takže oba motivy spojuje (Ungerman 2001).

Některá kování se nacházela $\mathrm{v}$ oblasti kolen zemřelých. Jde zřejmě o kování související s řemínky ovinutými kolem lýtek. Jde o hr. č. 53, 316 a 317. V hr. č. 53 ležely na holeních 2 půlkruhové přezky, v hr. č. 316 ležely 2 přezky s průvlečkami u pravého kolena, další oválná železná přezka a kování, zdobená plastickými pásky, byly mezi mečem a levým femurem. Železné oválné přezky byly nalezeny také u kolen kostry v hr. č. 317.

$\mathrm{V}$ hr. č. 35 leželo u hlavy zemřelého obdélné kování dlouhé asi $7,3 \mathrm{~cm}$, u hlavy se kování našlo také v hr. č. 71 . V hr. č. 52 byla oválná přezka spolu s nožem a vědérkem u nohou nebožtíka blíže ke stěně hrobové jámy.

Předměty denní potřeby: Nože se na lokalitě vyskytly v počtu 98 kusů pocházejících z 84 hrobů (tj. 35 \% všech hrobů). Šlo o hroby mužů (26 hrobů, tj. nůž se vyskytl v $84 \%$ vybavených mužských hrobů), žen (18 hrobů, tj. 64 \% vybavených ženských hrobů), dospělých jedinců neurčeného pohlaví (9 hrobů, 64 \% vybavených hrobů), nedospělých jedinců ( 9 hrobů, také $64 \%$ ) a dětí (22 hrobů, tj. $5121 \%$ vybavených dětských hrobů). Nože se obvykle v hrobě nacházely po jednom kuse, ale i po dvojicích a v jednom př́padě po trojici (hr. č. 332). Obvykle ležely v oblasti pasu (69 kusů), ale také v oblasti nohou (17 kusů), u hlavy (2 kusy, hr. č. 107 a 118), výše na trupu spočívaly 2 kusy (hr. č. 27 a 210), při levé ruce ležely 2 nože (hr. č. 1 a 123), u pravého ramene jeden nůž (hr. č. 316), stejný počet byl u levého ramene (č. 196). Ve čtyřech př́padech (hr. č. 26, 52, 85 a 181) nebyla poloha nože určena.

Základní rozdělení nožů provádím podle celkové délky, nebot' délka samotné čepele není v katalogu uvedena. Podle délky člením do kategorií jen ty nože, u nichž bylo možno délku odpovědně určit, nože, které jsou v natolik torzovitém stavu, že určení jejich 
rozměrů by bylo jen hrubým odhadem, do přehledů nezahrnuji. Tam, kde je v katalogu uvedena původní délka nože před konzervací, používám ji. Délku bylo možno určit u 62 nožů (63 \% všech nožů), nebylo ji možno určit u 36 kusů (cca 37 \% všech nožů).

Do $10 \mathrm{~cm}$ délky spadá 19 nožů (tedy přibližně $31 \%$ nožů s určenou délkou), délky 10 až $15 \mathrm{~cm}$ dosáhla naprostá většina nožů, a to 33 kusů (asi $53 \%$ nožů), nad $15 \mathrm{~cm}$ bylo dlouhých 10 nožů (cca $16 \%$ nožů). Nejdelší nůž měřil $20,6 \mathrm{~cm}$.

Zvláštní tvary se objevily v několika hrobech. Tzv. krevní rýhu měly nože z hr. č. 36, 38, 223 a 252. Celkem tři nože byly opatřeny př́čckou při trnu (hr. č. 208, 271 a 326). Nože z hrobů č. 24, 193, 314 a 317 měly hřbet zalomený tak, že se směrem ke špičce skláněl.

Nůž se jako součást hrobové výbavy objevil vždy v nadpoloviční většině vybavených hrobů jedné kategorie, jak bylo uvedeno výše. U dětí jím bylo vybaveno přes $50 \%$ hrobů, které poskytly výbavu, vybavené hroby nedospělých jedinců, žen a jedinců neurčeného pohlaví měly nůž v $64 \%$ př́padů. Nůž se však objevil v 26 mužských hrobech z 31 vybavených, tj. v 84 \% vybavených mužských hrobů. Je možné tedy poukázat na určitou preferenci nože ve výbavě mužů oproti jiným kategoriím. S tímto jevem snad také souvisí fakt, že existuje určitá závislost délky nože na věku a pohlaví. S kratšími noži byli pohřbeni především děti a nedospělí jedinci, s delšími muži (graf 12).

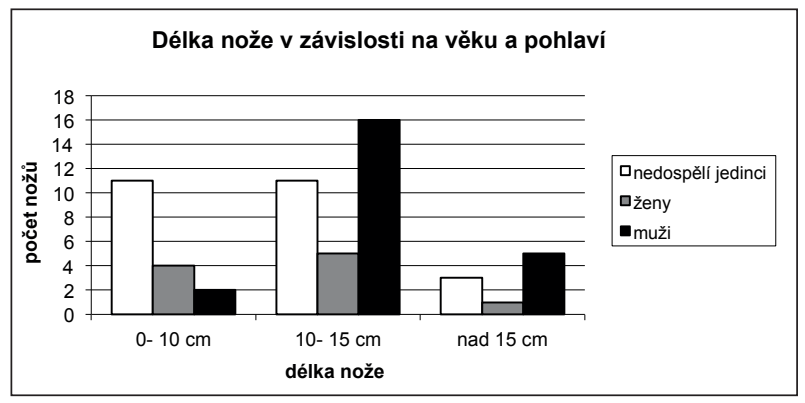

Graf 12. Délka nože v závislosti na věku a pohlaví. - Graph 12. Knife length depending on age and gender.

Ocílky se na lokalitě vyskytly v počtu 3 kusy. Šlo o hroby mužů (č. 18 a 118) a ženy (č. 57) věkové kategorie maturus. V jednom případě se ocílka našla $\mathrm{u}$ pasu, $\mathrm{v}$ jednom $\mathrm{u}$ pravého femuru a jednou $\mathrm{u}$ hlavy zemřelého. Ocílka z hrobu č. 18 měla rozšířený střed a zkrácená ramena a v hrobě se nacházela společně s rohovcovými úštěpy, exemplář z hrobu č. 57 měl lyrovitý tvar a v hrobě se objevil dohromady s rohovcovými úštěpy a nožem s vypouklým hřbetem. V hr. č. 118 se našla neúplná ocílka, dlouhá asi
$7 \mathrm{~cm}$. Spolu s ní se v hrobě nacházel rohovcový úštěp a dva nože. Na pohřebišti nevytvářely hroby s ocílkou žádnou koncentraci.

Vědro jako součást hrobové výbavy se objevilo v 13 hrobech (tj. přibližně $5 \%$ všech hrobů). Šlo o hroby dětí (4 hroby), žen ( 2 hroby), mužů ( 5 hrobů) a dospělých jedinců neurčeného věku a pohlaví (2 hroby). Védérko obvykle stálo u levé nohy zemřelého ( 6 případů) či u pravé nohy (4 případy) nebo obecně v oblasti nohou (3 případy). Je tedy zřejmé, že uložení vědérka se váže právě na tuto oblast. Koncentraci hrobů s vědérky můžeme sledovat v jižní polovině pohřebiště, blíže jeho středu. Hroby s vědry se však objevily i v severní části nekropole (2 hroby).

Vědérka s úzkými obručemi se objevila v 6 hrobech (č. 44, 52, 60, 301, 315 a 332). Na jednom vědérku mohly být i různě široké obroučky současně. Pokud byly zachovány rukojeti vědérek, byly knoflíkovitě ukončeny (nálezy z hr. č. 52, 60, 301 a 315), závěsná kování měla obvykle lichoběžníkový tvar a boční ramena.

Patrně pláštová vědérka se nalezla v 6 hrobech (č. 80, 87, 106, 108, 254 a 14). Opět převažovala rukojet' zakončená knoflíky (hr. č. 14, 80, 254), objevila se však i rukojet' hákovitě ukončená (hr. č. 87). Závěsná kování byla lichoběžníková (hr. č. 14, 87) nebo obdélná (hr. č. 254).

Vědérko z ženského hrobu č. 36 se spolu s nožem ihned rozpadlo, takže jeho typové zařazení není možné.

Břitva se objevila v hr. č. 263. Šlo o $8,3 \mathrm{~cm}$ dlouhý zlomek čepele s částí bočnice. Nacházela se u pasu spolu s dvěma noži. Kostra byla antropologicky určena jako ženská. Břitva v ženském hrobě je však netypické, je proto možné, že jde o špatné určení pohlaví.

Předmět z dětského hrobu č. 77 měl podobu masivní železné tyčinky kruhovitého průřezu přecházející v čepel podobnou nožíku. Předmět je dlouhý celkem $8,8 \mathrm{~cm}$ a jeho funkci není možné jednoznačně odhadnout.

Nůžky se vyskytly v mužském hr. č. 155. Zachovala se jen polovina ramene s lehce ven vyhnutým nasazeným obloukem. Ležely na vnitřní straně pravého femuru.

Srp (Č. Staňa zlomek určil jako fragment kosy) se nalezl v hr. č. 155. Šlo o zlomek břitu s trnem, rozpětí měl asi $11,1 \mathrm{~cm}$. Ležel u pravého kolena zemřelého, v hrobě byly také výše zmíněné nůžky, nádoba a šipka.

Bronzový rybářský háček se podařilo nalézt v ženském hr. č. 14. Byl vyroben ze silnějšího tordovaného drátu, který byl zahrocen, opačný konec je roztepán a svinut v očko. Háček ležel u pasu zemřelé. 
Bronzová jehla se objevila v hr. č. 14, na jednom konci byla zahrocená, na druhém roztepaná. Ležela u pasu zemřelé spolu s výše zmíněným háčkem.

V dětském hr. č. 9 se našla skoba, která ležela u trupu dítěte a nesouvisí tak pravděpodobně s úpravou hrobové jámy. V hrobě se pozůstatky rakve nenašly. Skoba je jednoramenná, $8 \mathrm{~cm}$ dlouhá.

V hr. č. 18 se našla bronzová rukojet' snad nože. Rukojet' má elipsovitý zploštělý tvar, členěný na 8 podélných plošek. Dlouhá je $4,9 \mathrm{~cm}$. Hrob obsahoval i nůž, ke kterému mohla patřit.

Keramika se našla celkem v 7 hrobech (č. 103, 155, 193, 216, 239, 262 a 336; tj. cca $3 \%$ všech hrobů). Šlo o hroby dětí (2 hroby), jedince věkové kategorie juvenis (1 hrob), hroby mužů (2 hroby), ženský hrob a dvojhrob ženy s dítětem (č. 239). Hroby s keramikou nevytvářely na pohřebišti žádné koncentrace, byly pravidelně rozloženy ve středové a severní části pohřebiště. Keramické nádoby ležely u levé nohy zemřelého (3 prrípady), u pravé nohy (1 případ), v hr. č. 103 byla nádoba rozbitá mezi kamenným obložením hrobu, v hr. č. 193 ležela nádoba na desce rakve obrácená dnem vzhůru, v dvojhr. č. 239 stála nádoba na stupni při stěně, nad hlavou ženy.

Zlomky keramiky se objevily také v zásypu hr. č. 148, 159 a 332. V hr. č. 148 šlo o střep od okraje slepený ze 7 zlomků. Dle Stani jde o střep z nádoby typu SZ 1/54. V zásypu hrobu č. 159 se našly dva střepy ze zrnitého materiálu, dva keramické zlomky se našly také v hr. č. 332, které jsou podle Stani také blízké okruhu typu SZ 1/54.

Je zajímavé, že ačkoliv se nacházíme v oblasti rozšíření blučinského okruhu (Poulík 1948, 85), nádoby této charakteristiky (vysoké štíhlé nádoby, kvalitní, zdobené jednoduchými rytými vlnicemi v kombinaci se šroubovicí (dle Mazuch 2013) se na pohřebišti nenacházejí. Blučinskému okruhu je příbuzná skupina SZ $1 / 54$, vyčleněná Č. Staňou na základě materiálu z výzkumu na hradišti Staré Zámky u Líšně (Staňa 1960). K tomuto typu náleží dle Č. Stani keramické zlomky ze zásypu dvou hrobů (č. 148 a 332), avšak žádná celá nádoba.

Připočteme-li k hrobům s keramickými nádobami hroby vybavené vědry, zjistíme, že na lokalitě bylo nádobou vybaveno celkem 20 hrobů, což představuje pouhých $8 \%$ všech hrobů na pohřebišti.

Skořápky ze slepičích vajec $\mathrm{v}$ počtu dvou kusů pocházejí z hrobu č. 235. Jde o hrob mladého jedince ve věku 14 až 15 let. Vejce ležela u hlavy zemřelého a v hrobě se mimo ně vyskytl nůž a ostruhy (shrnutí problematiky Smetánka 1998).

V dětském hr. č. 325 se našel kamenný závěsek kosodélníkového tvaru, vyrobený z plochého oblázku okrové barvy, s kruhovým otvorem při krátké, tenčí straně. Spočíval na hrudi dítěte a snad plnil funkci amuletu.
Kamenná štípaná industrie se našla v hrobech č. 18, 57, 118, kde tvořila příslušenství k ocílkám, které byly v těchto hrobech nalezeny. Surovinou byl rohovec či křištál (hr. č. 18).

Textil se objevil v 13 hrobech (č. 52, 53, 60, 75, 82, 124, 310, 314, 315, 316, 317, 323 a 327) v korozních vrstvách železných předmětů. Šlo zejména o tkaniny plátnové vazby (nálezy z hr. č. 53, 60, 75, 314, 315, $316,317,323$ ), ale i vazby keprové (hr. č. 315, 316, 317), sukna (hr. č. 316) či plsti (č. 317).

Pozůstatky kůže se podařilo nalézt na předmětech pocházejících z 10 hrobů (č. 53, 71, 124, 301, 314, 315, 316, 317, 323 a 332). Zbytky kůže a řemínků se nacházely při kováních, ostruhách, na meči z hrobu č. 316, na nožích a v dalších zlomcích rzi.

Některé předměty není možno přesněji interpretovat. Jde např. o zahrocenou železnou tyčinku z hrobu č. 118, dlouhou $5 \mathrm{~cm}$, či o zlomek drobného zahroceného předmětu z hrobu č. 123 . V hr. č. 314 se objevil drobný železný hrot s tulejkou.

\section{Prostorová analýza}

Rajhradická nekropole zaujímá nepravidelně trojúhelníkovitou plochu maximálně $70 \mathrm{~m}$ dlouhou a $42 \mathrm{~m}$ širokou, o rozloze asi $2100 \mathrm{~m}^{2}$. Plošina poskytovala dostatek místa pro šíření hrobů na všechny strany. Půdorys pohřebiště je podle Č. Stani uzavřený a okraje pohřebiště (až na východní okraj) jsou jisté, nebot tam byly odkryty dostačující plochy (Staňa 2006, 21-22). Při pohledu na plán odkrytých ploch (viz plán 2) je však zřejmé, že hroby se na více místech (zejména celý severovýchodní okraj pohřebiště) blíží až k okraji odkrytých ploch a je otázkou, kolik hrobů takto mohlo uniknout pozornosti. Počet hrobů, které nebyly odkryty, však snad není př́liš vysoký.

Hroby na pohřebišti se jen výjimečně navzájem porušovaly, což může ukazovat na to, že byly ve své době nějak povrchově označeny. Pouze 8 hrobů se nacházelo v superpozicích (hr. č. 155 a 157, č. 161 a 162, č. 228 a 229, č. 275 a 281; viz plán 7). Tyto hroby se na lokalitě objevují v její západní a severní části, vytvářejí oblouk při severozápadním okraji nekropole. Vzhledem k tomu, že tyto superpozice nejsou vyvolány nedostatkem místa na ploše pohřebiště a naopak dvojice (snad kromě té západně položené) mají kolem sebe dostatek volného prostoru, přichází v potaz myšlenka, že byly vedle sebe vyhloubeny, snad v krátkém časovém horizontu, oba hroby záměrně. Snad jde o příbuzné osoby.

Nekropole nebyla nijak členěna do okrsků podle věku a pohlaví. Ženské a mužské hroby všech věkových kategorií i hroby nedospělých jedinců věkové kategorie juvenis jsou volně rozloženy po celé plo- 


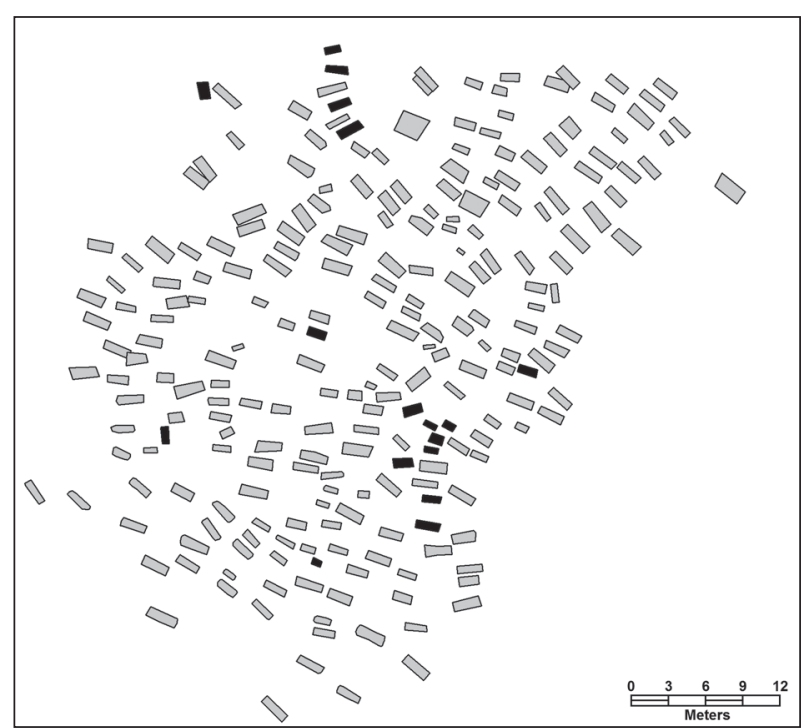

Plán 7. Hroby v superpozici. - Plan 7. Graves in superposition.

še pohřebiště bez výraznějších kumulací. Snad jen u dětských hrobů se může zdát, že jsou více koncentrovány v jihovýchodní části pohřebiště. Rozhodně však nemůžeme hovořit o vyčlenění areálu dětských hrobů.

$\mathrm{Na}$ pohřebišti můžeme sledovat různě dlouhé a různě pravidelné řady. Nejvýraznější jsou tři řady přibližně stejně orientovaných hrobů (azimuty 295 až $320^{\circ}$, tedy přibližně SZ orientace) na severovýchodním okraji nekropole. Další výrazná řada šesti hrobů se nachází na severním okraji pohřebiště. Čtyři hroby z těchto šesti (č. 174, 175, 181 a 183) jsou přitom orientovány obráceně, tzn. hlavou východním směrem (azimuty 74, 92, 56 a 63º). Výraznou řadu vytvárí také 5 hrobů (č. 230, 232, 196, 200 a 212) táhnoucích se směrem k severu od centrálního volného prostoru. Hroby jsou opět přibližně shodně orientovány. Další, tentokrát již méně výrazné řady stejně orientovaných hrobů se nacházejí také v jižní polovině nekropole. Skupinky v řadě umístěných hrobů se objevují na celé ploše pohřebiště, nejsou však, oproti výše zmíněným řadám, nijak výrazné.

Na ploše pohřebiště se nacházejí volná místa. Ta menší mohla souviset se stromy či keři (Staňa 2006, 21), zajímavý je však velký, téměř volný prostor přibližně uprostřed pohřebiště. Plocha, poněkud protáhlá v západovýchodním směru s rozměry přibližně 15 x 10 m, obsahuje jen 6 raně středověkých hrobů. Č. Staňa opatrně vyslovil myšlenku, že se může jednat o místo, na němž stál dřevěný kostel, jehož pozůstatky však nebyly pro značné narušení terénu při výzkumu zachyceny (Staňa 2006, 21-22; k problematice dřevěných kostelů Sommer 1997). Všechny raně středověké hroby na této ploše (č. 2, 231, 233,
254, 255 a 265) byly velmi mělké, dosahující i s ornicí hloubky 105, 77, 94, 105, 96 a $70 \mathrm{~cm}$. Volnou plochu je však možno interpretovat i jiným způsobem. 1) Ve volném prostoru se vyskytují četné únětické hroby, kterým se při hloubení raně středověkých hrobů snažili vyhnout. To však nevysvětluje, proč se nesnažili vyhnout se také únětickým hrobům severovýchodně od volné plochy, kde velkomoravské hroby starší únětické překrývají; 2) Celá dnes volná plocha byla původně navýšena, snad náspem mohyly. Pouze několik hrobů pak dosáhlo větší hloubky, a proto se dochovaly dodnes, zatímco ostatní hroby, umístěné v náspu, byly po staletí trvající zemědělskou činností zničeny. Možností, jak vysvětlit větší volnou plochu, zajisté existuje celá řada.

Domnívám se, že není možné sledovat prostorový vývoj rajhradického pohřebiště v čase, nebot' nelze vyčlenit na základě inventáře žádné chronologické horizonty (viz níže). Není možné sledovat hroby jednoho časového horizontu v prostorových vztazích a mluvit o starší či mladší části pohřebiště. Chronologicky citlivé předměty, zejména ostruhy, jsou v severní i jižní části pohřebního areálu a nevytvářejí žádné výrazné koncentrace. Domnívám se, že rozložení výklenkových hrobů či hrobů s kamennými konstrukcemi, kterým je obvykle přisuzován chronologický význam, může ukazovat i na jiné, např. sociální faktory.

\section{Datování pohřebiště}

Ačkoliv stav velkomoravské chronologie není uspokojivý (srov. např. Chorvátová 2004; Ungerman 2005; 2007; 2010), je třeba se pokusit o alespoň rámcové datování rajhradické nekropole. Při datování pohřebiště se opírám o př́tomnost či absenci chronologicky citlivějších předmětů, jako jsou šperky tzv. karantánského/předköttlašského horizontu, veligradský šperk, ostruhy či meč typu Y. V potaz je třeba brát také jevy, které s chronologickým faktorem možná souvisejí, jako je výskyt výklenkových hrobů a kamenných konstrukcí v hrobech.

Ženský šperk je zastoupen typy (podle Ungerman 2005) 7-1, 7-3, 7-10, 7-17, 7-19, 7-24, 8-10, 8-11, 8-12, 8-15, 9-6, 9-7, 9-14, 9-15, 9-18, 9-21, 9-23, 9-26, 9-27, 10-12, 10-13, 10-14, štítkovými prsteny, tepanými gombíky i gombíky zdobenými granulací a korálky. Z veligradského šperku se typy 8-10, 9-6, 9-14 a 9-21 vyskytují již v nejstarším horizontu pochovávání na pohřebišti ve Starém Městě Na Valách a jejich existenci tedy musíme předpokládat již v starším velkomoravském horizontu, jak jej vymezil Š. Ungerman (Ungerman 2005). Možný je však přesah jejich výskytu do mladšího velkomoravského horizontu, jehož materiální náplň není v současné době přesně defino- 
vána. Typ 8-10 se na pohřebišti v Rajhradicích vyskytuje společně s typy 8-11, 8-12, 9-15, 9-27 a tepanými gombíky, tedy typy šperků, jejichž datace do staršího velkomoravského horizontu není definována. Typ 9-6 se objevil pohromadě s typy 9-15 a 9-26, typ 9-14 s podunajským šperkem typu 7-1 a typ 9-21 s typy 9-7, 9-23 a tepanými gombíky.

Současně se na rajhradickém pohřebišti nevyskytují žádné předměty charakteristické pro tzv. předköttlašský/karantánský horizont (Giesler 1980; Korošec 1979; Ungerman 2005). Neobjevují se tu ani další předměty typické pro starší velkomoravský horizont jako korály zdobené nataveným vláknem, hadovité závěsky, prsteny se skleněnou vložkou typu 12-31, náušnice typu 8-13, 8-40 a 8-41, bubínkové náušnice typu 9-11 a lunicové náušnice typu 10-21 a 10-28 (Ungerman 2005). Na lokalitě se tedy nevyskytují žádné šperky, které by dovolovaly pohřebiště spolehlivě datovat do staršího velkomoravského horizontu. Naopak podélně členěné korály umožňují datování některých ženských hrobů do relativně mladšího období velkomoravského (či dokonce až do povelkomoravského) vývoje (např. Ungerman 2007, 112).

Ostruhy jsou na lokalitě zastoupeny pouze typem $\mathrm{s}$ řadou nýtů umístěnou příčně $\mathrm{k}$ rameni, a to jak s krátkým, tak prodlouženým bodcem. Ostruhy s nýty umístěnými podélně s ramenem nebo páskové ostruhy se, pokud bylo možno určit, na rajhradickém pohřebišti vůbec neobjevily. Tento fakt je důležitý pro chronologické závěry. Podle pozorování J. Košty (Košta 2008) jsou ostruhy s řadou nýtů př́ícnou k rameni mladší než ostruhy s dvěma řadami nýtů umístěných podélně a zároveň jsou současné s páskovými ostruhami. V absolutním datování se kladou do 2. poloviny 9. století až do počátku 10. století. Varianta s prodlouženými bodci patří dokonce až do povelkomoravského období. Ostruhy tedy nabízejí mladé datování mužských hrobů vybavených ostruhami.

Meč typu Y, který se nalezl v hr. č. 71, se ve velkomoravském prostředí vyskytuje jen vzácně, ve větší míře se naopak objevuje v Čechách 10. století (Košta 2004). Tento typ meče vychází po formální stránce $\mathrm{z}$ anglosaského meče typu L a začíná se vyrábět až na přelomu 9. a 10. století. Objevuje se pak v průběhu celého 10. století a jeho výskyt vyznívá až v 11. století (Košta 2005, 168). Je tedy zjevné, že hr. č. 71 je nutné datovat až do doby po přelomu 9. a 10. století, kdy se tento meč teprve začal vyrábět a poté, patrně s určitým časovým odstupem, byl uložen do země na rajhradické nekropoli.

Také rombická šipka z hrobu č. 155 může svědčit o mladém datování tohoto nálezového celku. Rombické šipky bývají často spojovány s Mad'ary a proto datovány až na sklonek velkomoravského období (např. Kouril 2003, 114).
V superpozicích se na lokalitě objevilo jen 8 hrobů, z nichž 4 hroby byly vybaveny. Tento stav samozřejmě neumožňuje využít superpozic k detailnímu chronologickému zpracování pohřebiště a k dalekosáhlým závěrům, přesto je nutné na tyto dvojice upozornit. Jde o dvojici hr. č. 155 a 157 a o dvojici č. 228 s 229. Můžeme zde uvažovat o jakési chronologické následnosti předmětů, které obsahovaly hroby uložené níže s předměty, které obsahovaly vrchní hroby, ačkoliv časový rozestup mezi vyhloubením těchto dvojic hrobů může být nepatrný.

Hrob č. 157 byl uložen nad hrobem č. 155. Obsahoval podunajský šperk typu 7-3, zatímco hr. č. 155 obsahoval keramickou nádobu, nůžky, kosu a rombickou šipku. Hrob s podunajským šperkem typu 7-3 je tedy relativně mladší než hrob s rombickou šipkou, která je obvykle považována za mladou a spojována s Mad'ary. Hrob č. 228, vybavený hrozníčkovými náušnicemi typu 8-12 a 8-15, ležel stratigraficky nad hrobem č. 229, který obsahoval ostruhy s řadou nýtů př́íčnou k rameni.

Stratigraficky níže jsou tedy uloženy hroby, jejichž výbava je obecně považována v rámci velkomoravské chronologie za mladší. Naopak nad těmito hroby leží celky obsahující veligradský šperk, jehož chronologie není, v zejména $\mathrm{v}$ mladším stupni, $\mathrm{v}$ současné době dostatečně propracovaná. Typy 7-3, 8-12 a 8-15 tedy musí být přinejmenším současné s ostruhami s řadou nýtů př́ícnou $\mathrm{k}$ rameni a rombickými šipkami. Tyto typy šperků se v jiných hrobových celcích kombinují s náušnicemi typu 7-19, 8-10, 8-11, 9-15 a 9-18; tyto tedy musejí být s nimi, alespoň z části, současné (viz kombinační tabulka). Otázku, jak dlouhá byla doba, kdy se daný typ do hrobů dostával a s kterými předměty se mohl kombinovat, stejně jako zda na základě jedné superpozice můžeme mluvit o mladém datování všech těchto typů, však není možné zodpovědět.

Na pohřebišti můžeme sledovat prvky, které snad s chronologií také souvisejí a které mohou být určitým vodítkem při jeho datování.

Výklenkové hroby bývají obvykle považovány za relativně starší a na pohřebištích se mají nacházet v starší části nekropole (Marešová 1983, 5; Staššíková-Štukovská 2004; 2006). Výskyt výklenkových hrobů podmolového typu má kulminovat v 9. století (Stašš́ková-Štukovská 2006), v mladších horizontech pochovávání do výklenkových hrobů zaniká (Staššíková-Štukovská 2001) a s nálezy charakteristickými pro 10. století, alespoň na Slovensku, se již výklenkové hroby nevyskytují (Staššíková-Štukovská 2006).

$\mathrm{Na}$ pohřebišti v Rajhradicích však tyto hroby neobsahovaly žádné nálezy, které by je mohly alespoň rámcově datovat a vyloučit či potvrdit jejich větší stáří. Výklenkové hroby se na lokalitě koncentrují blíže severnímu okraji nekropole a je otázkou, zda je tedy můžeme považovat za vývojově starší či nikoliv. 
Hroby s kamennými prvky jsou na lokalitě reprezentovány 21 hroby, z nichž 12 můžeme označit za záměrné konstrukce. Podle některých tvrzení mají kamenné konstrukce chronologický význam a mají být relativně mladší (např. Hanuliak 2004, 98-100). V Rajhradicích se hroby s kamennými prvky koncentrovaly ve střední části pohřebiště. Jen $8 \mathrm{z}$ nich obsahovalo výbavu, z níž jen ve 3 hrobech jde o předměty s možnou chronologickou citlivostí. Hrob č. 103 poskytl nález keramické nádoby, která v současné době v souboru chybí, a dvou korálků, skleněného dvojkonického a válcovitého, snad hliněného (v souboru chybí), v hr. č. 134 se nalezl pár náušnic typu 8-10 a drobný gombík zdobený palmetami a nakonec hr. č. 266 obsahoval dva stř́íbrné pozlacené gombíky zdobené rostlinným ornamentem. Tyto nálezy však neumožňují rozhodnout, zda opravdu jde o hroby spadající do mladší fáze velkomoravského období.

Domnívám se, že není možné při datování pohřebiště vycházet $\mathrm{z}$ obvyklého časového zařazení těchto jevů, zvláště pokud tyto hroby neobsahují žádný chronologicky citlivý inventář, který by dovoloval tyto teorie potvrdit či vyvrátit. Přri datování pohřebiště proto budu vycházet jen z chronologicky citlivých předmětů, byt' jsem si vědoma skutečnosti, že ani tento způsob není bez problémů.

Za současného stavu velkomoravské chronologie není možné na základě rozboru hrobových inventářo rajhradického pohřebiště sledovat jakékoliv chronologické horizonty. Na lokalitě se nevyskytly žádné předměty umožňující jednoznačně datovat hroby do starší fáze velkomoravského období. Naopak přítomnost nejmladších variant ostruh a přítomnost meče typu Y ukazuje dokonce na povelkomoravské datování některých hrobů. Domnívám se, že mladému datování na základě mužských hrobů neodporuje ani hrobový inventář, který obsahují ženské hroby. Doložené varianty šperků lokalitu nezařazují do staršího velkomoravského horizontu a přítomné varianty veligradského šperku nevylučují možnost datování pohřebiště až do závěru velkomoravského nebo i povelkomoravského období. Na lokalitě se zároveň nevyskytl typický ženský šperk mladohradištního období - esovité záušnice.

Záměrně se vyhýbám absolutním datům, domnívám se totiž, že stav bádání o raně středověké chronologii přesné vročení v současné době neumožňuje. Je možno pouze konstatovat, že pohřebiště se svým inventářem hlásí do mladší fáze velkomoravského vývoje, přičemž meč typu $\mathrm{Y}$ a snad také ostruhy s prodlouženým bodcem mohou ukazovat na přesah pohřbívání na lokalitě do první poloviny 10. století.

\section{Sociální kontext pohřebišš̌}

Materiál získaný na pohřebištích přináší celou řadu poznatků o pohřebním ritu, umožňuje nahlédnout do života tehdejší společnosti a snad také rekonstruovat vztahy v rámci společnosti. Interpretace sociálních vztahů však vyžaduje opatrnost. Téměř úplná absence písemných pramenů a analýza založená jen na rozboru hmotné kultury může být jednostranná až úplně zavádějící (Hanuliak 2004, 204). To, co má k dispozici archeologie, je jen pouhým zlomkem komplikované reality, obsah hrobu je součástí složitého pohřebního rituálu (Brather 2008, 252). Týž (2008, 255-256) přirovnává pohřební rituál k divadlu o třech účastnících - přítomni jsou nejbližší příbuzní, kteří pohřeb vystrojili, přihlížející skupina a sám zemřelý. Způsob pohřbu pak reaguje na potřeby, představy a přání všech zúčastněných. Během rituálu je se souhlasem všech přítomných prezentováno sociální postavení zemřelého a pozůstalých, a to nemusí vůbec odpovídat skutečnému stavu. Sociální postavení zemřelého není dáno pouze výší majetku, právním postavením a povoláním, ale odráží se v něm různé aspekty jako pohlaví, věk, příslušnost $\mathrm{k}$ rodině a popřípadě náboženství (Brather 2008, 259-260). Tyto aspekty se pak promítají také do hrobové výbavy. Je tedy nutné brát tyto faktory v potaz a sledovat bohatost výbavy v rámci jednotlivých skupin populace.

Může být ovšem složité odlišit od sebe sociální a chronologické faktory, nebot' oba faktory se prolínají. Sociální charakteristiky se proměňovaly v určitém čase. Př́kladem mohou být hroby bez výbavy - ve starším období mohou teoreticky ukazovat na nižší sociální postavení zemřelého a být tak především sociálním ukazatelem, kdežto spolu s christianizací a zánikem milodarů schopnost vypovídat o sociálním postavení ztrácejí. Prolínají se tu dvě roviny - sociální a časová. Změnami v průběhu času procházely i další parametry pohřebního ritu a proto také další charakteristiky v sobě ukrývají těžko rozlišitelný rozměr sociální a chronologický.

Jak bylo řečeno výše, na rajhradické nekropoli bylo vybaveno 54 \% všech hrobů. Z 31 vybavených mužů mělo v hrobě 14 jedinců ostruhy, jednou v kombinaci s mečem, jednou se sekerou. Druhá sekera nalezená v mužském hrobě se vyskytla dohromady se šipkou. Dá se tedy pozorovat, že zbraněmi byla opatřena přibližně polovina vybavených mužů. Další muže doprovázely do hrobu nože, vědra, keramické nádoby či ocílky. Militária v hrobových výbavách mají představovat symboly bojovnické moci a indikovat nadstandardní postavení zemřelého (např. Klápště 2005, 20-34). 


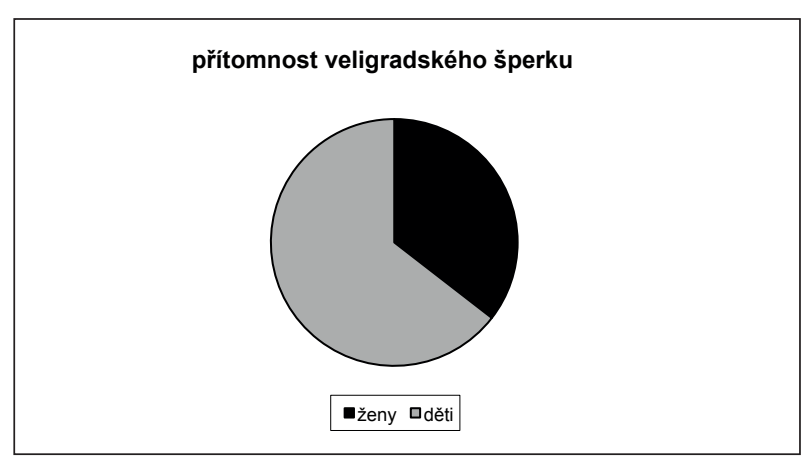

Graf 13. Zastoupení veligradského šperku v hrobech žen a dětí. - Graph 13. Representation of Veligrad jewellery in female and children graves.

Ženy byly vybaveny daleko skromněji, z 28 vybavených žen disponovalo jen šest žen veligradským šperkem. Zbylé ženy byly vybaveny prostším podunajským šperkem, noži a dalšími předměty denní potřeby. Pozoruhodný je hr. č. 201, v němž se nacházela kostra určená antropologem jako žena, obsahující však ve své výbavě sekeru, nebo ženský hr. č. 263 vybavený břitvou.

Veligradský šperk nebo gombíky obsahovalo 15 dětských hrobů. Můžeme tedy sledovat vyšší zastoupení luxusních šperků u dětí než u dospělých žen. Na tento jev poukazuje graf 13 - počet dětských hrobů s veligradským šperkem výrazně převyšuje počet takto vybavených ženských hrobů.

Celkem 22 dětských hrobů poskytlo nález nože, z toho tři můžeme považovat za „bojovéc. Na první pohled je patrné, že i velmi krátké nože byly ukládány do hrobů dětem, které je vzhledem ke svému věku nemohly nikdy užívat. V dětském hr. č. 212 byly uloženy ostruhy, v hr. č. 112 sekera. Zbraně v hrobech dětí jsou snad výrazem jejich př́slušnosti k vyšší bojovnické vrstvě společnosti, která dává takto najevo své prestižní postavení (Klápště 2005, 20-34; Kurasiński 2009, 233). V případě bohatého vybavení nedospělých dívek šperky je někdy spatřována „posmrtná svatba", kdy se mělo jednat o symbolickou svatbu neprovdané dívky spolu s pohřbem (Pollex 2003; kriticky Brather 2006).

Z 239 hrobů na lokalitě můžeme asi u 15 hrobů hovořit o bohatší výbavě. Jde o dětské hr. č. 80, 108, 112, 212, 332, hrob nedospělého jedince věkové kategorie juvenis č. 310, ženské hr. č. 27, 66 a 308, mužské hr. č. 315, 316, 317 a 323 a hroby antropology neurčených dospělých jedinců č. 71 (podle inventáře muž) a 251 (podle inventáře žena) (výbavy jednotlivých hrobů viz Staňa 2006).

Při hodnocení rajhradické nekropole po sociální stránce jsem lokalitu srovnávala s dvaceti velkomo- ravskými pohřebišti, jejichž publikační stav srovnání dovoloval. ${ }^{1}$

V Rajhradicích se vyskytují luxusní předměty, zejména veligradský šperk. Ten se sice objevuje i ve venkovském prostředí, jde však obvykle jen o hrozníčkové náušnice. V Rajhradicích luxusní typy sloupečkových, košíčkových a bubínkových náušnic spolu s gombíky ukazují na vyšší sociální prostředí. Př́tomnost mečů a ostruh se neváže jen na lokality s centrální funkcí, meče a ostruhy se vyskytují i ve venkovském prostředí, odkazují ale na prrítomnost elity. Do vyššího prostředí odkazuje také nákončí s křestanským motivem.

Také procentuální zastoupení vybavených hrobů vůči hrobům zcela bez nálezu této interpretaci neodporuje. Zatímco ve venkovském prostředí se vybavenost pohybuje kolem $70 \%$ hrobů a počet zcela nevybavených hrobů je nízký (např. v Dolních Věstonicích byla pouze třetina všech hrobů zcela bez nálezu (Ungerman 2007, 208), v Morkůvkách bylo vybaveno $72 \%$ hrobů (Měrínský - Unger 1990), ve Velkých Bílovicích 72,6 \% hrobů (Měrínský 1985, 26), pohřebiště na centrálních lokalitách vykazují mnohem menší podíl vybavených hrobů (např. Mikulčice -6 . kostel 36,5 \% (Profantová 2003), Modrá $39 \%$ (Hrubý - Hochmanová - Pavelč́k 1955) a více hrobů je zcela bez výbavy. Je patrné, že rajhradické pohřebiště se se svými $54 \%$ vybavených hrobů pohybuje někde uprostřed.

Rozdíl oproti venkovským pohřebištím můžeme zaznamenat i v př́tomnosti keramiky. Zatímco venkovská pohřebiště disponují velkým procentuálním zastoupením hrobů vybavených keramikou (nechvalínská pohřebiště 21 a $13 \%$; Prušánky $134,5 \%$ (Klanica 2006), Morkůvky 44 \% (Měrínský - Unger 1990), Horní Kotvice 30 \% (Marešová 1983), Dolní Věstonice $25 \%$ (Ungerman 2007), pohřebiště patřící k lokalitám s centrální funkcí se naopak vyznačují nízkým zastoupením keramiky v hrobech (Mikulčice 6. kostel 0,5\% (Profantová 2003); Staré Město - Na Valách 6,5 \% (Hrubý 1955). Pohřebiště v Rajhradicích

\footnotetext{
1 Dolní Věstonice (Ungerman 2007), Horní Kotvice (Marešová 1983), Mikulčice-Klášteřisko (Klanica 1985); hřbitovy u 6. a 12. kostele v Mikulčicích (Profantová 2003; Kavánová 2003); Modrá u Velehradu (Hrubý - Hochmanová - Pavelčik 1955), Morkůvky (Měrinský - Unger 1990), čtyři pohřebiště v Nechvalíně a Prušánkách (Klanica 2006), nekropole u kostela na Pohansku u Břeclavi (Kalousek 1971), Sady u Uherského Hradiště (Galuška 1996), Staré Město - Na Valách (Hrubý 1955) Velké Bílovice (Měrínský 1985). Ze slovenských lokalit jsem $\mathrm{k}$ rámcovému srovnávání použila pohřebiště v Bojničkách (Bialeková 1993b), Čakajovcích (Rejholcová 1995), v Nitře-Lupce (Chropovský 1962), pohřebiště v zázemí Pobedimi (Bialeková 1993; Vendtová 1969) a nekropoli ve Vel'kém Grobě (Chropovský 1957).
} 
pak svými $3 \%$ hrobů s keramikou jednoznačně odkazuje na prostředí nekropolí na centrálních lokalitách.

Za důležitý argument pro charakteristiku rajhradické nekropole jako místo posledního odpočinku sloužící lokalitě centrálního významu považuji také přítomnost hrobů s kamenným obložením. Při srovnání s dalšími velkomoravskými pohřebišti je zjevné, že se hroby s kamenným obložením v moravském prostředí vážou výhradně na pohřebiště patřící lokalitám s centrální funkcí, a to na nekropole kostelní. Ve venkovském prostředí, pokud je mi známo, se vůbec nevyskytují. Ze sledovaných lokalit se kamenné prvky objevily na pohřebišti v Mikulčicích, při 6. kostele, kde tvoři $10 \%$ všech hrobů (Profantová 2003), dále při 12. kostele, kde jsou zastoupeny $8,8 \%$ (Kavánová 2003), ve Starém Městě - Na Valách 1,6 \% (Hrubý 1955), v Sadech u Uherského Hradiště (Galuška 1996) představovaly hroby s kamenným obložením asi jen $1 \%$, zde se však vyskytují zděné hrobky, které ponechávám stranou. Kamenné konstrukce se objevily také na Pohansku při kostele (Kalousek 1971) a v Mikulčicích-Klášteřisku (Klanica 1985). Hroby jednoznačně s kamenným obložením představují v Rajhradicích asi $5 \%$ všech hrobů. Domnívám se, že i tento jev podporuje zařazení nekropole mezi pohřebiště centrálních lokalit.

O sociální struktuře může vypovídat i index maskulinity (v Rajhradicích s hodnotou 768). Podle I. Štefana a I. Krutiny mají venkovské lokality obvykle poměr mezi pohlavími přibližně vyrovnaný (tzn., že index maskulinity se pohybuje kolem 1000), u pohřebišt patřících k centrální lokalitě je výkyv na jednu či druhou stranu téměř charakteristickým rysem (Štefan - Krutina 2009, 188). Některá venkovská pohřebiště však toto pravidlo popírají (např. Josefov, Štefan - Krutina 2009, 189).

Jedině výklenkové hroby mohou svědčit o opaku evidentně se totiž častěji nacházejí na venkovských lokalitách a na pohřebištích patřících lokalitám centrálního významu se objevují jen zř́ídka. Domnívám se, že více argumentů však svědčí pro interpretaci rajhradické nekropole jako místa, které (vedle běžných obyvatel) sloužilo k pohřbívání elit, příslušejících k lokalitě s centrální funkcí.

Nyní se nabízí otázka, o jaké centrum šlo. Pro možnou odpověd' nemusíme chodit daleko, na dohled od rajhradické nekropole se nachází klášter v Rajhradě. Podle břevnovských falz z konce 13. století klášter v Rajhradě založil kníže Břetislav I. v roce 1045 a klášter měl vzniknout na zaniklém hradě jménem Raygrad. Zmínka obou listin o tom, že klášter byl založen v místě staršího hradu, budila pozornost již v minulosti. Již I. L. Červinka nepochyboval o starším velkomoravském předchůdci rajhradského kláštera. Tvrdil sice, že stopy opevnění dávno zmizely pod stavbou klášterních budov, název však že „svědči na hradiště staroslovanské, které založil nebo na němž velel Ráj" a že na jeho existenci mohou odkazovat také nálezy hrobů učiněných v 19. století u Rebešovic (Červinka 1928, 93). Důkazem existence hradiště má být plán kláštera stavitele Annaise z 18. století s vyznačenými valy, název Rajhrad („rajský hrad“, tj. hrad zbudovaný v oblasti bohaté na vodu (Skutil 1983, 238-239), text obou břevnovských falz, sídlištní nálezy datovatelné do 9. až 10. století, a také bohatá pohřebiště na k. ú. Rajhradu a Rajhradic (Skutil 1983, 235-236; Staňa 1961, 92). Situace přitom není vůbec jednoduchá. Valy známé z plánů stavitele Annaise byly během přestaveb kláštera zničeny a celá plocha uvažovaného hradiště značně pozměněna jak výstavbou kláštera, tak regulací řeky Svratky v 19. století (Staňa 1961).

Archeologické poznatky o klášterním areálu jsou dosud velmi omezené. V roce 1951 provedl J. Poulík zjištovací výzkum v klášterní zahradě, během něhož nalezl v kulturní vrstvě raně středověké střepy, dva mlýnské kameny, zvírecí kosti, mazanici a uhlíky (Staňa 1961, 92). Další výzkum provedl v roce 1952 J. Nekvasil. Objevil opět raně středověkou kulturní vrstvu datovatelnou dle keramiky do 9. až 10. století s propálenou hlínou, uhlíky a ohořelými dřevy (Staňa 1997, 597; Nekvasil 1954, 437). Za účelem objevení archeologických pozůstatků valu a zjištění jeho stáří provedl další výzkum Č. Staňa v roce 1960 . Ve třinácti sondách výzkum zachytil velkomoravskou kulturní vrstvu, dva depoty zemědělských předmětů a destrukce srubových staveb datovatelných rovněž do velkomoravského období. Dle Stani tyto sruby svou orientací respektovaly průběh valu známého z plánů a tudíž je značně pravděpodobné, že se raně středověké opevnění nacházelo ve stejných místech jako tyto valy. Podle Stani je tedy „však možno přijmout její pravděpodobnou návaznost na průběh velkomoravského opevnèní a tedy územní kontinuitu slovanského hradiska a benediktinského kláštera." (Staňa 1997, 597). Vlastní výzkum valu v sondě 13 však žádné takové poznatky nepřinesl. Jeho destrukce je na základě keramiky datovatelná do přelomu 12. a 13. století a pod touto destrukcí se již jiný materiál nenacházel (Staňa 1961; 1997).

Proti interpretaci opevnění známého z plánů i ze sondy číslo 13 Staňova výzkumu jako pozůstatků raně středověkého opevnění vystoupil J. Unger, který v roce 1993 provedl v areálu kláštera záchranný výzkum (Unger 1997). Během tohoto výzkumu se nepodařilo objevit kulturní vrstvy velkomoravského stář́, nejstarší vrstva je datovatelná do 1. poloviny 13. století, nepodařilo se doložit ani aktivity kláštera 11. až 12. století. Podle Ungera byl však rozsah sond natolik malý, že neumožňuje řešit složité otázky ohledně stavebního vývoje kláštera (Unger 1995). Kulturní vrstvy velkomoravského stárí nebyly zachy- 
ceny ani při výzkumu v areálu kláštera v letech 20002001 (Zapletalová 2002, 18).

Po novém detailním rozboru publikovaných nálezových situací dospěla také $\mathrm{D}$. Zapletalová k názoru, že pro existenci velkomoravského hradiště nedisponujeme žádnými důkazy. Doloženo je dle ní pouze velkomoravské sídliště východně od klášterního areálu, ale pro prokázání opevnění velkomoravského stáří by bylo zapotřebí provést další archeologické výzkumy v areálu kláštera (Zapletalová 2002).

Je však otázkou, zda se lokality s centrální funkcí musely být vždy opevněny. Př́kladem může být hradiště Pohansko u Břeclavi, kde podle nových dendrologických datování opevnění vzniklo až v samém závěru velkomoravského vývoje (Dresler - Humlová Macháček - Rybníček - Škojec - Vrbová-Dvorská 2010, 135-136; Dresler 2011, 180). Dvorec, jehož starší fáze má podle tradičního datování spadat do 1. poloviny 9. století (např. Dresler 2011, 24), tedy snad dlouhou dobu nebyl součástí opevněné plochy. Je tedy možné, že také v Rajhradě existoval jen dvorec obklopený sídlištěm, k němu př́íslušelo rajhradické pohřebiště. Proč by se však rajhradické pohřebiště nacházelo ve značné vzdálenosti od hradiště a nikoliv v jeho bezprostřední blízkosti, zůstává otevřenou otázkou. Řešení by snad v budoucnu mohly přinést další výzkumy v areálu rajhradského kláštera, jejichž poznatky však budou vzhledem $\mathrm{k}$ zástavbě vždy omezené.

\section{Závěr}

Předložený článek přinesl rozbor raně středověkého pohřebiště v Rajhradicích. Sledovali jsme jednotlivé znaky pohřebního ritu a tyto jevy charakterizovali. Na základě provedeného rozboru je možné pohřebiště datovat, a to do závěru velkomoravského období s určitým přesahem do období povelkomoravského. Lokalita nese znaky pohřebišt patřících centrálním lokalitám, v žádném př́ipadě se nepodobá dosud známým venkovským nekropolím. Je tedy nutno hledat lokalitu centrálního významu, ke které toto významné pohřebiště patřilo. Nabízí se areál rajhradského kláštera, na jehož místě na základě falza ze 13. století nacházelo hradiště, jehož existence však není potvrzena.

\section{Prameny}

Král, J. 1954: Rebešovice 1952. Kostrové pohřebiště slovanské, únětické a stěhování národů (výzkum na podzim 1952). Nálezová zpráva v archivu AÚ Brno, č. j. $1665 / 54$.

Nekvasil, f. 1954: Zachraňovací výzkum v roce 1953 v Rebešovicích. Nálezová zpráva v archivu AÚ Brno, č. j. $1664 / 54$.
Staňa, Č. 1954: Rebešovice 1953, únětické a slovanské kostrové hroby (8.-9. 7. 1953). Nálezová zpráva v archivu AÚ Brno, č. j. 945/54.

Staňa, Č. 1977: Rajhradice 1975. „Stráně“ u Rebešovic. Slovanské a únětické pohřebiště. Nálezová zpráva v archivu AÚ Brno, č. j. 1981/77.

\section{Literatura}

Bialeková, D. 1977: Sporen von slawischen Fundplätzen in Pobedim, Typologie und Datierung, Slovenská archeológia 25, 103-158.

Bialeková, D. 1993a: Slovanské pohrebisko v Pobedime (poloha Na Laze II/71), Študijné zvesti 29, 179-207.

Bialeková, D. 1993b: Slovanské pohrebisko v Bojničkách, Študijné zvesti 29, 223-258.

Brather, S. 2006: „Totenhochzeit“? Zur Interpretation altersabhängiger Grabausstattungen bei den westlichen Slawen. In: M. Dworaczyk et al. (eds.), Świat Słowian wczesnego średniowiecza. Szczecin - Wrocław, 505-513.

Brather, S. 2008: Kleidung, Bestattung, Identität. Die Präsentation sozialer Rollen im frühen Mittelalter. In: S. Brather (ed.), Zwischen Spätantike und Frühmittelakter. RGA-E, Band 57. Berlin - New York, 237-273.

Brůžek, J. 2008: Současná česká paleodemografie: falešné naděje př́lišného optimismu a nový reálný cíl, Archeologické rozhledy 60, 329-344.

Červinka, I. L. 1928: Slované na Moravě a říše velkomoravská. Brno.

Dostál, B. 1966: Slovanská pohřebiště ze střední doby hradištní na Moravě. Praha.

Dresler, P. - Humlová, B. - Macháček, J. - Rybníček, M. Škojec, f. - Vrbová-Dvorská, f. 2010: Dendrochronologické datování raně středověké aglomerace na Pohansku u Břeclavi. In: Š. Ungerman - R. Přichystalová (eds.): Zaměřeno na středověk: Zdeňkovi Měřínskému k 60. narozeninám. Praha. 112-138, 750-752.

Dresler, P. 2011: Opevnění Pohanska u Břeclavi. Dissertationes archaeologicae Brunenses 11. Brno.

Galuška, L. 1996: Uherské Hradiště - Sady. Křestanské centrum říše velkomoravské. Brno.

Galuška, L. 2001: Neznámé slovanské pohřebiště u Vranovic (okr. Břeclav) a jediné nálezy z něj pocházející. In: Z. Měřínský (ed.): Konference Pohansko 1999. 40 let od zahájení výzkumu slovanského hradiska Břeclav-Pohansko. Brno, 185-197.

Giesler, J. 1980: Zur Archäologie des Ostalpenraumes von 8. bis 11. Jahrhundert, Archäologisches Korrespondenzblatt 10/1, 85-98.

Hanáková, H. - Staňa, Č. - Stloukal, M. 1986: Velkomoravské pohřebiště v Rajhradě. Praha.

Hanuliak, M. 2004: Velkomoravské pohrebiská. Pochovávanie v 9. -10. storočí na území Slovenska. Nitra.

Hendrychová, S. 2011: Velkomoravské pohřebiště v Rajhradicích. Rukopis bakalářské práce, FF UK, Praha.

Hrubý, V. 1955: Staré Město. Velkomoravské pohřebiště „Na Valách". Praha.

Hrubý, V. - Hochmanová, V. - Pavelčík, f. 1955: Kostel a pohřebiště z doby velkomoravské na Modré u Velehradu. Brno.

Chorvátová, H. 2004: K relatívnej chronológii pohrebiska Staré Město - Na valách, Acta Historica Neosoliensia 7, 199-235.

Chorvátová, H. 2008: K problému terminológie a interpretácie gul'ovitých príveskov-vel'komoravských gombíkov, Studia mediaevalia Pragensia 8, 209-218. 
Chropozský, B. 1957: Slovanské pohrebisko z 9. storočí vo Vel'kém Grobe, Slovenská archeológia 5, 174-239.

Chropozský, B. 1962: Slovanské pohrebisko v Nitre Na Lupke, Slovenská archeológia 10, 175-240.

Kalousek, F. 1971: Břeclav-Pohansko. Velkomoravské pohřebiště u kostela. Brno.

Kavánová, B. 2003: Mikulčice - pohřebiště v okolí 12. kostela. In: N. Profantová - B. Kavánová: Mikulčice. Pohřebiště u 6. a 12. kostela. Brno.

Klanica, Z. 1985: Mikulčice-Klášteřisko, Památky archeologické 76, 474-539.

Klanica, Z. 2006: Nechvalín, Prušánky. Čtyři slovanská pohřebiště. Díl I., II. Brno.

Klápště, f. 2005: Proměna českých zemí ve středověku. Praha.

Kodym, O. - Fusán, O. - Matějka, A. 1967: Geologická mapa ĆSSR. Praha.

Korošec, P. 1979: Zgodnjesrednjeveška arheološka slika karantanskih Slovanov. Ljubljana.

Košta, f. 2004: Výpověd' souboru raně středověkých mečů ze staromoravského centra $\mathrm{v}$ Mikulčicích. Rukopis diplomové práce, FF UK, Praha.

Košta, 7. 2005: Přehled vývoje mečů karolinského typu, Středočeský vlastivědný sborník 23, 159-172.

Košta, f. 2008: Několik poznámek k chronologii pohřebiště u VI. Kostela v Mikulčicích, Studia mediaevalia Pragensia 8, s. 277-296.

Kouřil, P. 2003: Staří Mad'aři a Morava z pohledu archeologie. In: J. Klápště - E. Plešková - J. Žemlička (eds.): Dějiny ve věku nejistot: sborník k př́ležitosti 70. narozenin Dušana Třeštíka. Praha, 894-906.

Krumphanzlová, Z. 1961: K otázce vampyrismu na slovanských pohřebištích, Památky archeologické 52, 544-549.

Kurasinski, T. 2009: Militaria jako element wyposażenia wczesnośredniowiecznych pochówków dziecięcych próba interpretacji na przykładzie znalezisk z ziem polskich, Archeologia Polski 54, 209-248.

Marešová, K. 1983: Uherské Hradiště-Sady. Staroslovanské pohřebiště na Horních Kotvicích. Brno.

Mazuch, M. 2013: Velkomoravské keramické okruhy a tzv. mladší velkomoravský horizont v Mikulčicích. Brno.

Měrínský, Z. - Unger, f. 1990: Velkomoravské kostrové pohřebiště u Morkůvek (okr. Břeclav). In: Pravěké a slovanské osídlení Moravy. Sborník k 80. narozeninám Josefa Poulíka. Brno, 360-401.

Měrínský, Z. 1985: Velkomoravské kostrové pohřebiště ve Velkých Bílovicích. K problematice venkovských pohřebišt' 9.-10. stol. na Moravě. Praha.

Neuhäuslová, Z. a kol. 2001: Mapa potenciální přirozené vegetace České republiky. Praha.

Pollex, A. 2003: Die Totenhochzeit. Ein Beispiel zur Dekodierung slawischen Toteninventare mit Hilfe von Quellen zum neuzeitlichen Volksglauben. In: U. Veit et al (eds.): Spuren und Botschaften. Interpretation materialler Kultur. Münster, 385-398.

Poulik, J. 1948: Staroslovanská Morava. Praha.

Profantová, $\mathcal{N}$. 2003: Mikulčice - pohřebiště u 6. kostela: Pokus o chronologické a sociální zhodnocení. In: N. Profantová - B. Kavánová: Mikulčice. Pohřebiště u 6. a 12. kostela. Brno.

Rejholcová, M. 1995: Pohrebisko v Čakajovciach (9.-12. storočie). Nitra.

Ruttkay, A. 1976: Waffen und Reiterausrüstung des 9. bis zur ersten Hälfte des 14. Jahrhunderts in der Slowakai, Slovenská archeológia 24, 245-395.
Smetánka, z. 1993: Archeologie ochranného zvuku, Dějiny a současnost 1/93, 7-9.

Smetánka, Z. 1998: Archeologie ptačího vejce, Dějiny a současnost 20, 7-10.

Sommer, P. 1997: Raně středověká ecclesia lignea a archeologie. In: Z pravěku do středověku. Sborník k 70. narozeninám Vladimíra Nekudy. Brno. 276- 278.

Skutil, 7. 1983: Raně středověký Rajhrad a jeho místní i funkční proměny, Historická geografie 21, 235-253.

Staňa, Č. 1960: Slovanské obytné objekty na hradišti Staré Zámky u Líšně, Památky archeologické 51, 240-293.

Staňa, C̆. 1961: Zjištovací výzkum na slovanském hradišti v Rajhradě. Přehled výzkumů 1960, 92-94.

Staňa, C̆. 1997: Anfänge des Klosters in Rajhrad im Lichte der archäologischen Quellen. In: J. Mař́ḱková-Kubková et al. (eds.): Život v archeologii středověku. Praha, 597-609.

Staňa, Č. 2006: Velkomoravská pohřebiště v Rajhradě a Rajhradicích. Katalog. Brno.

Stǎ̌šíková-Štukovská, D. 2001: Vybrané nálezy z pohrebiska v Borovciach z pohladu začiatkov kostrového pochovávania staromoravských a nitrianských Slovanov. In: L. Galuška - P. Kouřil - Z. Měřínský (eds.): Velká Morava mezi Východem a Západem. Sborník př́spěvků z mezinárodní vědecké konference. Brno, 371-388.

Staššíková-Štukovská, D. 2004: Prínos pohrebiska v Borovciach $\mathrm{k}$ výskumu raného stredoveku. In: Balneologický spravodajca, Vlastivedný zborník múzea 2001-2002 (Balneohistorica Slovaca 38). Pieštany, 150-157.

Stašš́ková-Štukovská, D. 2006: Problematika včasnostredovekých výklenkových hrobov, Študijné zvesti 39, 77-84.

Stloukal, M. a kol. 1999: Antropologie. Př́ručka pro studium kostry. Praha.

Štefan, I. 2009: Frühmittelalterliche Sonderbestattungen in Böhmen und Mähren. Archäologie der Randgruppen?, Ethnographisch-Archäologische Zeitschrift 50, 139-162.

Štefan, I. - Krutina, I. 2009: Raně středověké sídliště, hromadný hrob a pohřebiště na Budči, Památky archeologické, 119-212.

Tolasz, R. a kol. 2007: Atlas podnebí Česka. Praha - Olomouc. Tomáśek, M. 2007: Půdy Ceské Republiky. Praha.

Unger, f. 1995: Nová zjištění a nové otázky z areálu rajhradského kláštera, Jižní Morava 34, 218-228.

Unger, f. 1997: Rajhrad (okr. Brno-venkov), Přehled výzkumů 1993-94, 232-234.

Ungerman, Š. 2001: Poznámka k velkomoravskému nákončí z Rajhradic (okr. Brno-venkov), Sborník prací Filozofické fakulty Brněnské univerzity M 6, 167-176.

Ungerman, S. 2005: Ženský šperk staršího velkomoravského horizontu, Archeologické rozhledy 57, 707-749.

Ungerman, Š . 2007: Raně středověké pohřebiště v Dolních Věstonicích - Na Pískách. Rukopis dizertační práce, FFMU, Brno.

Ungerman, $\breve{S}$. 2010: Počátky mladohradištních pohřebišt' na Moravě. In: Š. Ungerman - R. Přichystalová (eds.): Zaměřeno na střredověk: Zdeňkovi Měŕínskému k 60. narozeninám. Praha, 220-239.

Ungerman, Š. 2011: Schwertgurte des 9. bis 10. Jahrhunderts in West- und Mitteleuropa. In: J. Macháček Š. Ungerman (eds.): Frühgeschichtliche Zentralorte in Mitteleuropa Studien zur Archäologie Europas 14. Bonn, 575-608.

Vendtová, V. 1969: Slovanské osídlenie Pobedima a okolia, Slovenská archeológia 17, 119-232.

Zapletalová, D. 2002: Několik poznámek k velkomoravskému Rajhradu. In: Brno v minulosti a dnes 16, 13-31. 


\section{Great Moravian burial ground in Rajhradice}

The presented article discusses the early medieval burial ground in the cadastral community Rajhradice (Brno-Country District). It offers complex evaluation of the burial ground in terms of spatial, chronological and social analysis.

The burial ground was examined in 1952-1953 and in 1975 under the leadership of J. Král, J. Nekvasil and Č. Staňa. It was uncovered in its entirety and represents a complete set for further processing. The catalogue of the burial ground was published in 2006 .

The remains of a total of 244 individuals from 239 graves were uncovered at the burial ground. Anthropological material from the burial ground was processed by Jan Jelínek of the Moravian Museum (MZM) and Milan Stloukal of the National Museum (NM), but their findings have not been published yet. Out of the 244 individuals subjected to anthropological analysis, the gender of 25 adults was undetermined, and the age of 24 of the dead was impossible to estimate more closely. The necropolis included 90 children, 30 members of juvenis category without determination of the gender, 43 men and 56 women. The masculinity index of the Rajhradice necropolis amounts to 767.857. The number of persons burying their dead at the burial site might have been 76 or 137 (given the duration of the necropolis for 100 or 50 years).

An utter majority of the grave pits were of rectangular shape in top view; the graves maintained the common eastwest orientation with northward deviations. The necropolis contained alcove graves, graves with partial or complete stone cladding and graves fitted with coffins, which even comprised $52 \%$ of all the graves. No individuals laid in a non-standard position were discovered at the locality, only seven graves slightly differed from the ordinary rite. Five double graves were discovered at the necropolis.

A total of 129 graves at Rajhradice burial ground (54\% of all the graves at the necropolis) contained grave goods, whereas 110 graves (46\%) did not. Higher equipment of male graves compared to other population groups can be observed. The grave goods at the burial ground were rich: the locality contains luxury Veligrad jewellery (basket-shaped, column-shaped and other earrings), gombik buttons, a belt-end decorated with a Christian motif as well as militaria - axes, spurs with a line of rivets transverse to the arm and a Y-type sword. A ceramic vessel was only found in seven graves.

The Rajhradice necropolis is situated on an irregular triangular territory with the maximum length of 70 metres and maximum width of 42 metres, covering the area of approximately 2,100 square metres ${ }^{2}$. The graves at the burial ground only exceptionally violated one another, which may signal that they were labelled in some way on the surface in their time. Only eight graves were located in superposition. The necropolis was not divided into districts according to age or gender. We can see lines of different length and regularity at the burial ground, as well as free spaces. While the smaller ones might have been connected with trees or bushes, a large, almost free space approximately in the centre of the burial ground attracts interest. The area of approximately $15 \times 10$ metres, somewhat elongated in west-east direction, contains only six early medieval graves. Č. Staňa carefully expressed an idea that it might have been the location of a wooden church whose remnants were not detected because of significant disruption of the terrain during the research. Alternative interpretations of the situation are also possible, however: for example that the free space was originally raised above the surrounding terrain, the early medieval graves did not reach the bedrock with their bottoms and were therefore destroyed without trace. It is impossible to monitor the spatial development of Rajhradice burial ground in time, because no chronological horizons can be singled out based on the inventory (see below). Chronologically sensitive items, above all spurs, are located in both northern and southern parts of the burial area, forming no substantial concentrations.

Although the state of Great Moravian chronology is not satisfactory, it is necessary to attempt at least at rough dating of the Rajhradice necropolis. No chronological horizons can be followed based on the analysis of the grave inventories of Rajhradice burial ground. No items enabling unambiguous dating of the graves into the older stage of the Great Moravian period occurred at the locality. On the contrary, the presence of the most recent variants of spurs and of the Y-type sword is indicative of even post-Great-Moravian dating of some graves. I am of the opinion that the grave goods contained in the female graves does not contradict recent dating based on the male ones. The documented variants of jewellery do not classify the locality into older Great Moravian horizon, and the present variants of Veligrad jewellery do not rule out the possibility of dating the burial ground to the end of the Great Moravian period, or even past it. The burial ground therefore can be dated to younger Great Moravian or post-Great-Moravian horizon. At the same time, a typical female jewel of the young-stronghold period, S-shaped earrings, did not appear at all at the locality.

From the viewpoint of the social structure, we can state that the burial ground is closer to a church necropolis than to rural graveyards by its character. Luxury Veligrad jewellery and militaria appear at the locality, while the representation of ceramics is low; stone constructions, unknown from the rural milieu, appear there. The character of a burial ground belonging to a central locality may be supported also by the presence of luxury "imported" fir wood, the absence of extraordinary positions of the dead, the masculinity index or the estimate of the size of community burying their dead there. The burial ground in Rajhradice therefore most probably belonged to a central locality.

The question that offers itself is which centre it was. We need not go very far to find the answer: the monastery of Rajhrad, which was according to written sources founded on the site of an older stronghold, is located nearby. No fortification has been archaeologically proven yet. However, I am of the opinion that a locality with central functions did not always have to include fortifications. In any case, the burial ground in Rajhradice testifies to the presence of a central locality.

\author{
Soňa Hendrychová \\ Ústav pro archeologii FFUK \\ Celetná 20 \\ email: sona.hendrychova@seznam.cz
}

